\title{
Governance of professional service firms: a configurational approach
}

\author{
Dirk Harlacher $\cdot$ Markus Reihlen
}

Received: 10 August 2011/Accepted: 3 September 2013/Published online: 23 May 2014

(C) The Author(s) 2014. This article is published with open access at Springerlink.com

\begin{abstract}
Professional service firms (PSFs) such as accounting firms, management consultancies, or advertising agencies use very different forms of governance ranging from traditional professional partnerships to public corporations. In spite of the extensive literature, little academic work has been done to synthesize the wealth of theoretical and empirical work on PSF governance into a more comprehensive theory of PSF governance. Taking configuration theory as our theoretical approach, we identify three classes of design parameter (legal form, organizational governance structure, and the systems for managing professionals) and six contingency factors (service commoditization, service diversification, firm size, capital intensity, firm culture, and risk of litigation) that are synthesized into four configurations of PSF governance. These are described, respectively, as the founder-dominated, the collegial, the managerial, and the entrepreneurial configuration.
\end{abstract}

Keywords Professional service firms - Governance - Professional partnership - Public corporation - Configuration theory - Archetype theory

JEL Classification G34 · L84

Responsible editor: Peter Walgenbach (Management).

D. Harlacher

Cologne, Germany

e-mail: harlacher@gmx.de

M. Reihlen ( ()

Leuphana University of Lüneburg, Otto Group Chair of Strategic Management, Scharnhorststraße 1, 21335 Lüneburg, Germany e-mail: reihlen@leuphana.de 


\section{Introduction}

The question of governance of professional service firms (PSFs) was a largely neglected area of research until Greenwood et al. (1990) article on managing professional partnerships. In partnerships, ownership and management are fused in the partners, who control their business through collegial decision-making and a form of representative democracy (Brock 2006; Empson 2006, 2007; Empson and Chapman 2006; Greenwood and Empson 2003; Greenwood et al. 1990; Hinings et al. 1991). Much of the subsequent work has been devoted to describing deviations from the professional partnership form, identifying alternative archetypes such as the corporate managed professional business form (Hinings et al. 1999; Morris and Pinnington 1999; Pinnington and Morris 2002) or the Global Professional Network (Brock, Powell and Hinings 1999b; Brock et al. 2007). Yet this rich vein of work has presented a dichotomous view on governance of PSFs, in which firms choose between professional partnerships versus corporations, between collegial clan control versus corporate hierarchy, or between professional bureaucracy versus adhocracy (Mintzberg 1979: 348-379, 431-467). As Empson (2012) argues a good deal of governance systems and practices cannot be captured by these dichotomized models. For instance, in its early days Bain \& Company, a management consulting firm, had formally been a partnership, but strongly centralized control in the person of the founder Bill Bain (Williamson and Yoshino 1994). Another counter example is Greenberg Traurig limited liability partnership (LLP), a fast growing Miamibased law firm that established a highly entrepreneurial governance system, in which collegial or hierarchical controls are replaced by an internal market system fostering strong partner autonomy and individual performance controls (Kolz 2007). Both cases are at odds with existing models of PSF governance and demand a treatment of PSF governance "beyond dichotomies" (Empson 2012) that would account for a broader range of governance types.

To overcome these limitations of existing research constrained to the analysis of the partnership and/or corporate form of governance, we draw on the large number of contingency studies providing evidence for particular patterns of empirical relationships between situational variables and governance dimensions that have not been systematically exploited in previous studies. In order to make a distinctive contribution, this study takes a configurational approach (Meyer et al. 1993; Miller 1987, 1996; Mintzberg 1979; Weber 1978) to PSF governance that allows us to synthesize existing literature by developing ideal types or configurations that can facilitate and guide future theorizing as well as empirical research. We build upon Harlacher's (2010) earlier investigation and offer a revised configuration model.

We propose three classes of design parameters (legal form, organizational governance structure, and the systems for managing professionals) and six contingency factors (service commoditization, service diversification, firm size, capital intensity, firm culture, and risk of litigation) that are synthesized into four configurations of PSF governance (the founder-dominated, the collegial, the managerial, and the entrepreneurial configuration).

The structure of the paper is as follows: first, we introduce configuration theory as our conceptional framework and explain how we adopt this framework to address 
questions of PSF governance. Then we define and describe our three groups of design parameters and explain contingency factors related to the strategy, organization, and environment of the firm and discuss their effects on specific design parameters. We will then take the interdependencies explicitly into account by synthesizing them into four configurations of PSF governance. Finally, we discuss our configurations in the light of previous research. The paper closes with concluding thoughts.

\section{Configuration theory and governance}

Configuration theory has been widely used in organization studies (Albers 2005; Dess et al. 1993; Miles and Snow 1978; Mintzberg 1979; Short et al. 2008) and has become a major school of thought (Mintzberg 1990; Wolf 2000). In contrast to contingency theory, configuration theory aims to understand organizations in a systemic way, "lumping together" (Mintzberg 1990) a significant number of different factors resulting in rich descriptions of idealized types of organizations (Meyer et al. 1993).

The basic assumption underlying configuration theory is that among the almost unlimited number of permutations of organizational and situational variables, only a few will be useful for understanding organizations and predicting their behavior (Miller 1981, 1986). Mintzberg (1979: 216-226, 299-304) describes this in terms of three hypotheses regarding successful configurations. First, an effective organization structure requires a close fit between situational factors and structural design parameters. Second, the design parameters must be internally consistent. Third, combining the first two hypotheses, successful configurations achieve consistency among both design parameters and situational factors. Configurations thus derive their usefulness from describing a few ideal types which should match their real counterparts approximately (Bunge 1996; Meyer et al. 1993; Miller and Friesen 1984).

A set of configurations can generally be determined in three ways. It can be derived conceptually, usually referred to as a typology, or can be empirically grounded, usually called a taxonomy (Meyer et al. 1993; Miller 1996). Since typologies are based on theoretical considerations, they should have strong explanatory power and facilitate further empirical work. The best typologies are "neat, memorable, and evocative" (Miller 1996, 506). Taxonomies are founded on quantitative data and describe patterns or clusters in the data. Since a certain data set is the basis, taxonomies may suffer from lack of theoretical significance or from unreliable results, thus producing conflicting or ambiguous findings (Miller 1996). Proponents of PSF archetype theory have taken a third, though also empirical approach to develop configurations. This approach uses the "identification of the interpretive scheme and of how that relates to structural attributes and processes" as a starting point "to uncover coherent patterns of organizing" (Greenwood and Hinings 1993, 1055).

In our paper, we follow the first approach by theoretically constructing a typology of PSF governance models. Following previous research on PSF 


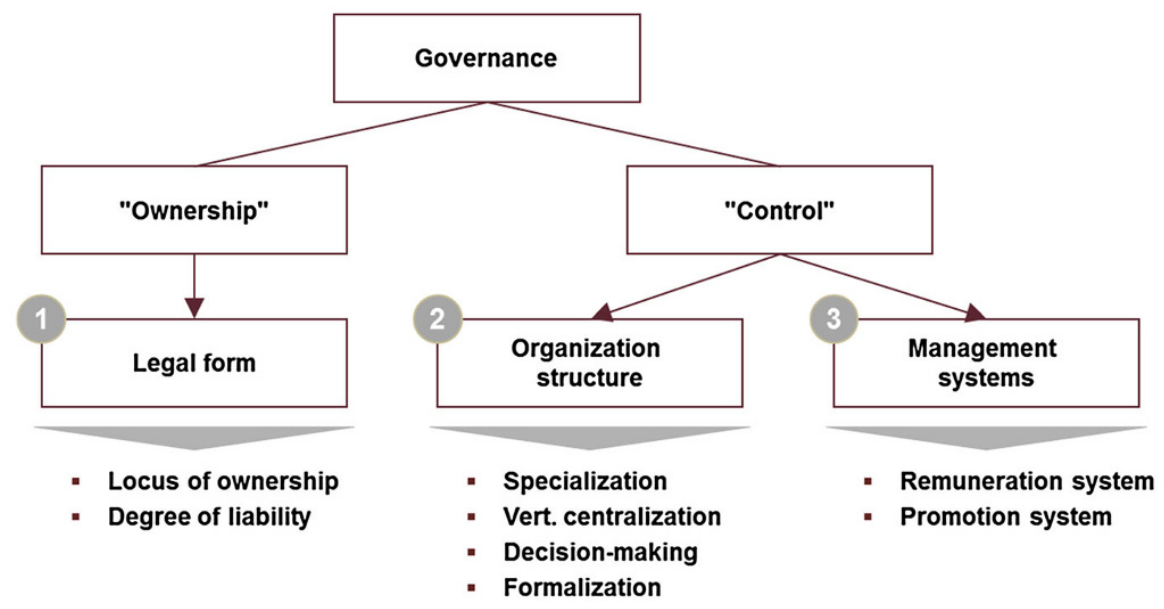

Fig. 1 Design parameters of PSF governance

governance we consider both ownership and control as aspects of firm governance. While owners have a formal right to control the firm and appropriate the firm's profits, the effective control is actually exercised through organizational structures and systems (Hansmann 1996). As a consequence, governance of PSFs has to address different groups of governance dimensions (see Fig. 1). First, it has to specify different ownership types or legal forms of PSFs (Empson and Chapman 2006; Greenwood and Empson 2003). Second, regarding the dispersion of the effective right to control throughout the organization, we have to incorporate dimensions concerning the organization structure that determines who is in control and who is held accountable for specific actions. Drawing on earlier governance studies (Albers 2005; Brown et al. 1996; Empson and Chapman 2006), we distinguish specialization, centralization, degree of participation in decisionmaking, and formalization as key structural features of the organization of PSF governance. Third, the framework has to address the unique systems designed to manage professionals. Following Lorsch and Tierney (2002), we regard remuneration and promotion decisions as "critical governance issues" for PSFs that "vitally affect the organization's future" (p. 129) and, therefore, focus our analysis on firms' remuneration and promotion systems.

In addition, we reviewed studies from the literature on PSFs as well as the more general organization studies literature to identify factors that influence the choice of particular governance design parameters. In total, we identified six different contingency factors that influence several or all of the governance dimensions. In his call for a configurational approach in organization studies, Miller argues that "there exist at least three classes of factors which are necessary to richly describe the process of organizational adaptation" (Miller 1981, 8), those being strategy, environment, and organization. In our case, we identified service commoditization, diversification, and size (related to firm's strategy), capital intensity and culture (related to the organization), and the risk of litigation (related to the environment) as 


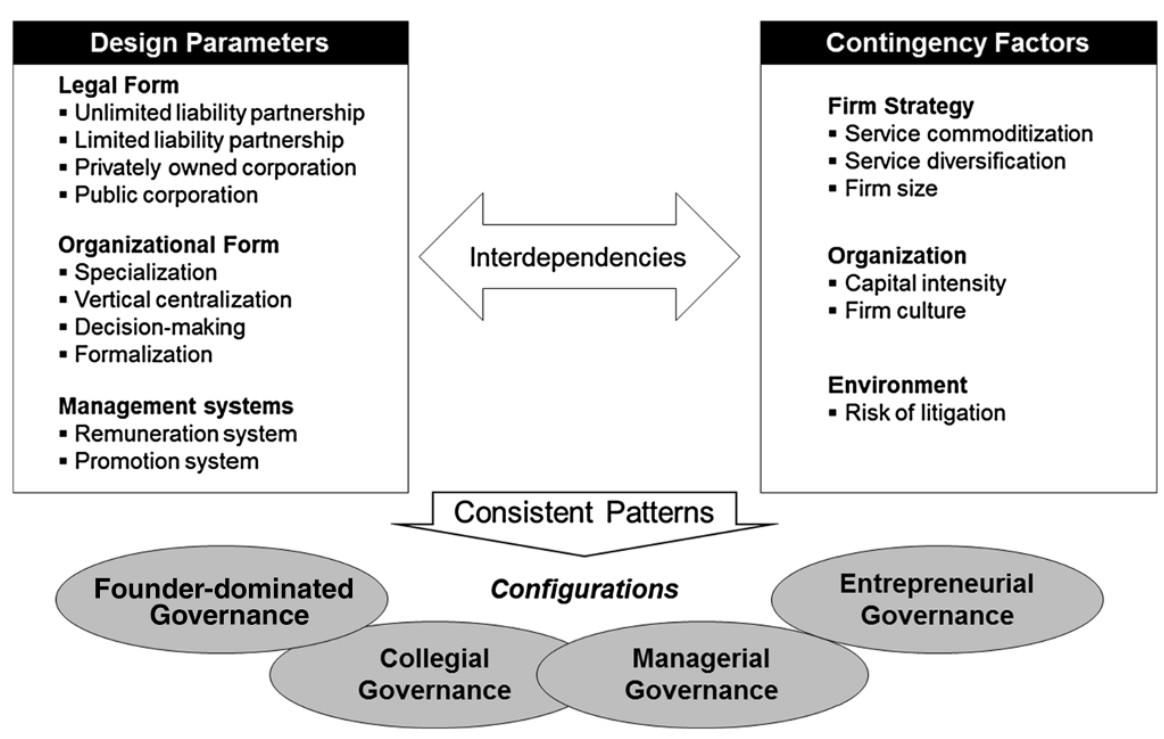

Fig. 2 Constructing configurations of PSF governance

significant contingency factors. In order to identify consistent configurations we developed a matrix of cause and effect relationships describing theoretically or empirically grounded interrelationships between contingency factors and governance dimensions. The last step was to identify those consistent patterns and organize them meaningfully around unifying themes or imperatives (Miller 1987). We identified four imperatives of PSF governance referring to leadership, collegiality, managerial hierarchy, and entrepreneurial growth. These four imperatives correspond to the founder-dominated, collegial, managerial, and entrepreneurial configuration, respectively. A summary of our approach to PSF governance configurations is presented in the following Fig. 2.

\section{Design parameters of PSF governance}

\subsection{The legal form of PSF governance}

Four legal forms of governance are generally distinguished for PSFs: the public corporation, the privately held corporation, the LLP, and the general (i.e. unlimited liability) partnership (Empson and Chapman 2006; Greenwood and Empson 2003). The main characteristic that distinguishes partnerships and private corporations from public corporations is the locus of ownership, which lies with professionals working in the firm in the former cases, and with external shareholders in the latter case. Partnerships and private corporations are distinguished by the degree of ownership liability. Legal details vary by jurisdiction, but a private corporation usually has limited liability. In a general partnership, however, all partners share 
unlimited personal liability for actions of other partners taken on behalf of the partnership. Over the past 20 years, the LLP has been introduced as a legal form that has elements of both partnership and corporation (McCahery 2004) as partners usually do not have personal liability for the actions of other partners (for differences of UK and US LLPs see McCahery and Vermeulen 2004; Bank 2006; Morse 2004; Bromberg and Ribstein 2007).

\subsection{The organizational structure of PSF governance}

\subsubsection{Specialization of control rights}

An organization structure shall be called unspecialized, if few different organizational units are distinguished regarding the distribution of control rights in the firm and shall be called specialized, if many different organizational units are distinguished (Graubner 2006). Many large PSFs are specialized according to at least three characteristics (Greenwood et al. 2010). The first and obvious characteristic is geography, establishing different offices and sometimes regional office systems within the PSF. The other two characteristics are client industry (e.g., financial services, automotive or pharmaceuticals) and type of service (e.g., M\&A and tax law in a law firm, or corporate strategy and organization in a management consulting firm). They establish what are usually called practice areas, competence centers, service lines, or areas of expertise. A professional will usually belong to one office, but may belong to several "practice areas." For simplicity, we will refer to the structural entities that result from specialization, be they offices, regional office systems, or practice areas as organizational units.

\subsubsection{Centralization of control rights}

Centralization and decentralization are concepts that have received wide attention in the literature and have been defined in many different ways (Kieser and Walgenbach 2007, 194-196; Mintzberg 1979: 181-213). Central to most of these definitions is the distribution of power (Hall 2002), which is closely related to the distribution of effective control rights. Decentralization deals with the dispersion of control rights from the top to lower levels of the organization. For our definition of centralization, we again employ the concept of organizational units: if many control rights are retained at the level of the firm, i.e. the decisions made affect the whole firm, rather than only subsidiary organizational units, and few are exercised at subsidiary levels, we call the organization structure centralized. Conversely, if few control rights are retained at the level of the firm and many are exercised at subsidiary levels, we refer to a decentralized organization structure. The lower the level of those organizational units, where most control rights are exercised, the more decentralized is the organization. On an organizational level, the governance dimension of centralization distinguishes a "one firm" governance model from a "network firm" model, in which the subsidiary parts may have great independence from the parent firm and may even be regarded as individual PSFs (a "network of firms" model). 


\subsubsection{Degree of participation in decision-making}

The degree of participation in decision-making is widely employed in the literature and often referred to decision-making being either collegial or hierarchical (e.g., Greenwood and Empson 2003; Tolbert and Stern 1991). An organization structure shall be called hierarchical, if few professionals, who are members of an organizational unit, share the effective right to control this unit. Conversely, an organization structure shall be called collegial, if many professionals in an organizational unit share the effective right to control this unit. The decision-making dimension is concerned with the distribution of control rights within the individual organizational units, not with the number of units or the distribution of control rights among them.

\subsubsection{Formalization of control rights}

We call an organization structure formalized, if many control rights are exercised ex ante by defining rules and regulations for different contingencies. We refer to an organization structure as not formalized, if many control rights are exercised ad hoc without a reduction of discretion due to rules and regulations. For example, a committee responsible for determining which young professionals should be promoted at a certain time may take ad hoc decisions or follow a set of predefined rules regulating promotional decisions. The degree of formalization can be differentiated according to the object of formalization. This can be a certain process that is carried out within the organization structure, the output of such a process, or a certain position or role in the organization structure (Mintzberg 1979: 81-94). In the latter case, the rights and duties of a position are specified. In the absence of formalized positions, the distribution of control rights may well be contested and different organizational members may claim the right to make certain decisions. Formalization of positions by specifying rights and duties reduces the ambiguity of the distribution of control rights within an organization.

\subsection{Management systems for professionals}

\subsubsection{Remuneration system}

The remuneration system of a PSF determines how its professionals are paid. The simplest type of remuneration system pays every professional a fixed income according to his or her position. For incentive reasons, at least part of a professional's income will often be contingent on performance, even if the professional is not an owner of the firm. We differentiate between three different types of contingent income. First, lockstep remuneration divides the income that is contingent on firm performance according to seniority. The lockstep remuneration system is considered the traditional profit sharing system for PSFs with internal ownership, especially partnerships. Historically, partnerships in the US were required to have profit-sharing rules close to equal sharing (Levin and Tadelis 2005, 156). Under this system, all partners of a certain seniority level (i.e., who have been 
partners for the same number of years) receive the same profit share, irrespective of their billings or any other performance measure. However, the concept of dividing contingent income according to seniority is applicable to non-partner professionals as well. The lockstep system is thought to facilitate collegial interaction among professionals, such as internal referrals, knowledge sharing, and teamwork, since "the only way to improve individual remuneration is to improve overall profitability" (Angel 2007, 204). A drawback of the lockstep system is that freeriding and shirking are encouraged if collegial controls among profit-sharing professionals fail (e.g., Fama and Jensen 1983a; Leibowitz and Tollison 1980). Second, eat-what-you-kill remuneration awards contingent income according to some measure of individual output that makes a direct contribution to firm profits, such as client charges or hours billed. More and more firms have introduced performance-based elements into their remuneration system in recent years, both on the partner level (e.g., Griffiths 2005) and on the non-partner level (e.g., Williams 2007), although the elite British law firms especially have been reluctant to abandon the lockstep system (Angel 2007; Begum 2007). The eat-what-you-kill system discourages free-riding and shirking and makes it easier to retain "star" professionals that contribute disproportionately strongly to total firm profits (Levin and Tadelis 2005), possibly at the expense of collegiality, since time spent supporting other professionals may not be counted as own contribution to firm profits and thus may not be incentivized financially. While lockstep and eat-whatyou-kill remuneration have been the focus of the PSF literature, we will introduce a third type of remuneration system: Scorecard remuneration determines contingent income according to some measure of individual behavior, such as feedback on client interaction, leadership skills, etc. provided by other professionals or even clients. Of course, all three systems can be combined in the compensation of a single professional, yet they represent conceptually distinct remuneration systems.

\subsubsection{Promotion system}

In partnerships or similarly organized PSFs, up-or-out promotion systems have traditionally been the norm, especially in elite firms (e.g., Gilson and Mnookin 1989; Smigel 1969). Under such a system, professionals are denied permanent tenure unless they are elected partner. Professionals who are not elected partner within a specified number of years are fired or expected to leave the firm (Morris and Pinnington 1998). The up-or-out system was pioneered by Paul Cravath around 1900 and is also known as the "Cravath system" (Nelson 1988, 71-72; Swaine 1948). In some PSFs, especially law firms, the up-or-out process applies only at the point of partner selection, whereas in other PSFs, such as management consulting firms, the up-or-out promotion system usually covers several promotion levels, and professionals who are not promoted to the next level are expected to leave. In recent years, exceptions to the up-or-out promotion system have become increasingly more common, creating permanent positions in PSFs (Gilson and Mnookin 1989; Morris and Pinnington 1998, 1999; Sherer and Lee 2002). Under this model, professionals are granted permanent tenure without being promoted to full partner status and becoming residual claimants. Instead, they may enjoy some of the partner privileges 
and responsibilities and bear titles such as "specialist", "junior partner", or "salaried partner." Usually, firms that have previously employed the up-or-out promotion system will not abandon it completely, but use permanent positions as an option to retain professionals who are valuable to the firm, but, for whatever reason, are not elected partner.

\section{Contingency factors of PSF governance}

In this section, we review studies from the literature on PSFs as well as the more general organization studies literature to identify factors that influence the choice of particular governance models along the dimensions developed in the previous section. In total, we identify six different contingency factors that influence several or all of the governance dimensions. In the following, we will summarize some of the most important findings of this research for each set of contingency factor. A more comprehensive explication of 38 contingency hypotheses and their supporting theoretical/empirical evidence is presented in Table 1.

\subsection{Service commoditization}

Professional services are generally thought to be customized to "particular cases" (Abbott 1988). A commodity service, on the other hand, is delivered to many different clients without being adapted to the individual circumstances of any particular client and is available from several different service suppliers. Commodity services (such as car insurance or a bank transfer) are not regarded as professional services. Yet among professional services, there are considerable differences regarding the degree of customization or commoditization (Hansen et al. 1999; Maister 1993). Some professional services that used to require the case-bycase application of expert judgment have been largely commoditized through professional standards and technological advances. For example, the traditional core service provided by accounting firms, the audit itself, has been commoditized through accounting standards and computer technology, which has reduced quality differences between the providers. Several studies (Alchian and Demsetz 1972; Fama and Jensen 1983a, b; Levin and Tadelis 2005; Morrison and Wilhelm 2004) imply a relationship between the degree of service commoditization in PSFs and their locus of ownership, with different ways of reasoning. Despite differing theoretical backgrounds, they allow the conclusion that PSFs offering customized services are more efficiently run with internal ownership, whereas PSFs offering commoditized services are better off having external ownership. Similarly, service commoditization and formalization of control rights are closely related. As service delivery is increasingly repetitive, it is efficient to formalize the processes and outputs of service delivery, as well as the organizational roles and positions involved in it. Hansen et al. (1999) show how knowledge management processes in accounting and consulting firms vary according to the commoditization or customization of services. Service commoditization also affects the systems used to manage professionals. In a firm that delivers highly commoditized professional 
Table 1 Selected hypotheses on the relation between contingency factors and PSF design parameters

\begin{tabular}{|c|c|c|}
\hline Contingency factor & Hypothetical relation with design parameter & Supporting evidence \\
\hline \multirow[t]{10}{*}{$\begin{array}{l}\text { Service } \\
\quad \text { commoditization }\end{array}$} & $\begin{array}{l}\text { Effects on locus of ownership } \\
\text { Hypothesis 1.1: The greater the degree of service commoditization, the } \\
\text { more likely a PSF will have external ownership, ceteris paribus }\end{array}$ & $\begin{array}{l}\text { Alchian and Demsetz (1972); Dow and } \\
\text { Putterman (2000); Fama and Jensen } \\
\text { (1983a); Greenwood and Empson } \\
\text { (2003); Levin and Tadelis (2005); } \\
\text { Morrison and Wilhelm (2008) }\end{array}$ \\
\hline & Effects on specialization & Mintzberg (1979) \\
\hline & $\begin{array}{l}\text { Hypothesis 1.2: The specialization of control rights will increase with } \\
\text { the degree of service commoditization, ceteris paribus }\end{array}$ & \\
\hline & $\begin{array}{l}\text { Effects on decision-making } \\
\text { Hypothesis 1.3: The higher the degree of service commoditization, the } \\
\text { more hierarchical the distribution of control rights will be, ceteris } \\
\text { paribus }\end{array}$ & $\begin{array}{l}\text { Maister (1993); Alvesson (1995) for the } \\
\text { case of service customization }\end{array}$ \\
\hline & $\begin{array}{l}\text { Effects on formalization } \\
\text { Hypothesis 1.4: The higher the degree of service commoditization, the } \\
\text { more formalized the organization structure will be, ceteris paribus }\end{array}$ & $\begin{array}{l}\text { Alt (2006); Armbrüster (2006); } \\
\text { Hansen et al. (1999); Morris and } \\
\text { Empson (1998) }\end{array}$ \\
\hline & Effects on the remuneration system & Alchian and Demsetz (1972) \\
\hline & $\begin{array}{l}\text { Hypothesis } 1.5 \mathrm{a} \text { : The higher the degree of service commoditization, } \\
\text { the less a PSFs remuneration system will rely on contingent income, } \\
\text { ceteris paribus }\end{array}$ & \\
\hline & $\begin{array}{l}\text { Hypothesis } 1.5 \mathrm{~b} \text { : The higher the degree of service commoditization, } \\
\text { the more contingent income will be distributed according to } \\
\text { scorecard remuneration, ceteris paribus }\end{array}$ & \\
\hline & Effects on the promotion system & Levin and Tadelis (2005); McKenna \\
\hline & $\begin{array}{l}\text { Hypothesis 1.6: The higher the degree of service commoditization, the } \\
\text { less likely a PSF is to use an up-or-out promotion system, ceteris } \\
\text { paribus }\end{array}$ & $\begin{array}{l}\text { (2006); Morris and Pinnington } \\
\text { (1998) }\end{array}$ \\
\hline \multirow[t]{7}{*}{ Service diversification } & $\begin{array}{l}\text { Effects on specialization } \\
\text { Hypothesis 2.1: The greater the degree of service diversification, the } \\
\text { more specialized a PSF's organization structure will be, ceteris } \\
\text { paribus }\end{array}$ & $\begin{array}{l}\text { Brock et al. (2007); Greenwood et al. } \\
\text { (2002); Rose and Hinings (1999); } \\
\text { Greenwood and Suddaby (2006) }\end{array}$ \\
\hline & Effects on centralization & Amburgey and Dacin (1994); Rumelt \\
\hline & $\begin{array}{l}\text { Hypothesis 2.2: The greater the degree of service diversification, the } \\
\text { more decentralized a PSF's organization structure will be, in } \\
\text { particular if it is highly specialized, ceteris paribus }\end{array}$ & (1974); Williamson (1975) \\
\hline & Effects on decion-making & Amburgey and Dacin (1994); Brock \\
\hline & $\begin{array}{l}\text { Hypothesis 2.3: The greater the degree of service diversification, the } \\
\text { more hierarchical will be the distribution of control rights, } \\
\text { especially at the firm level or similarly comprehensive } \\
\text { organizational units, ceteris paribus }\end{array}$ & $\begin{array}{l}\text { et al. (1999a); Greenwood and } \\
\text { Empson (2003); Malhotra et al. } \\
\text { (2006); Rose and Hinings (1999) }\end{array}$ \\
\hline & Effects on remuneration system & Koza and Lewin (1999); Nelson \\
\hline & $\begin{array}{l}\text { Hypothesis } 2.4 \text { : The greater the degree of service diversification, the } \\
\text { less likely a PSF is to use a lockstep remuneration system, ceteris } \\
\text { paribus }\end{array}$ & $\begin{array}{l}\text { (1988); Sherer (2007) } \\
\text { Counter position: Gilson and Mnookin } \\
\text { (1985) }\end{array}$ \\
\hline
\end{tabular}


Table 1 continued

\begin{tabular}{|c|c|c|}
\hline Contingency factor & Hypothetical relation with design parameter & Supporting evidence \\
\hline \multirow[t]{7}{*}{ Firm size } & $\begin{array}{l}\text { Effects on locus of ownership } \\
\text { Hypothesis 3.1: The likelihood of a PSF having external ownership } \\
\text { will increase with firm size, ceteris paribus }\end{array}$ & $\begin{array}{l}\text { Alchian and Demsetz (1972); Demsetz } \\
\text { (1983); Dow and Putterman (2000); } \\
\text { Fama and Jensen (1983a); Leibowitz } \\
\text { and Tollison (1980); Morrison and } \\
\text { Wilhelm (2004) }\end{array}$ \\
\hline & $\begin{array}{l}\text { Effects on the degree of liability } \\
\text { Hypothesis 3.2: The likelihood of a PSF having unlimited liability will } \\
\text { significantly decrease with increasing firm size, ceteris paribus }\end{array}$ & $\begin{array}{l}\text { Alchian and Demsetz (1972); Bank } \\
\text { (2006); Fama and Jensen (1983a); } \\
\text { Morrison and Wilhelm (2004) }\end{array}$ \\
\hline & $\begin{array}{l}\text { Effects on specialization } \\
\text { Hypothesis } 3.3 \text { : The specialization of control rights increases with firm } \\
\text { size, ceteris paribus }\end{array}$ & $\begin{array}{l}\text { Greenwood and Hinings (1993); } \\
\text { Mintzberg (1979); Montagna (1968); } \\
\text { Graubner (2006) }\end{array}$ \\
\hline & $\begin{array}{l}\text { Effects on centralization } \\
\text { Hypothesis } 3.4 \text { : The centralization of control rights decreases with } \\
\text { increasing firm size, ceteris paribus }\end{array}$ & $\begin{array}{l}\text { Child (1972); Hinings and Lee (1971); } \\
\text { (Pugh et al. 1969); Graubner (2006) }\end{array}$ \\
\hline & $\begin{array}{l}\text { Effects on decision-making } \\
\text { Hypothesis } 3.5 \text { : Hierarchical decision-making increases with firm size, } \\
\text { ceteris paribus }\end{array}$ & $\begin{array}{l}\text { Blau (1984); Greenwood and Empson } \\
\text { (2003); Tolbert and Stern (1991) }\end{array}$ \\
\hline & $\begin{array}{l}\text { Effects on formalization } \\
\text { Hypothesis } 3.6 \mathrm{a} \text { : The formalization of control rights increases with } \\
\text { firm size, ceteris paribus } \\
\text { Hypothesis } 3.6 \mathrm{~b} \text { : The use of standardization of processes and outputs } \\
\text { increases with firm size, ceteris paribus } \\
\text { Hypothesis } 3.6 \mathrm{c} \text { : The use of mutual adjustment and direct supervision/ } \\
\text { fiat decreases with increasing firm size, ceteris paribus }\end{array}$ & $\begin{array}{l}\text { Blau (1984); Graubner (2006); } \\
\text { Lawrence and Lorsch (1967); } \\
\text { Malhotra et al. (2006); Mintzberg } \\
\text { (1979) }\end{array}$ \\
\hline & $\begin{array}{l}\text { Effects on the remuneration system } \\
\text { Hypothesis 3.7: The use of lockstep remuneration systems will } \\
\text { decrease with firm size, ceteris paribus }\end{array}$ & $\begin{array}{l}\text { Gilson and Mnookin (1985); Farrell } \\
\text { and Scotchmer (1988); Kummel } \\
\text { (1996); Levin and Tadelis (2005); } \\
\text { Nelson (1988); Sherer (2007); Power } \\
\text { and Begum (2004) }\end{array}$ \\
\hline $\begin{array}{l}\text { Financial capital/ } \\
\text { capital-intensive } \\
\text { assets }\end{array}$ & $\begin{array}{l}\text { Effects on locus of ownership } \\
\text { Hypothesis 4: The higher the amount of financial capital required by a } \\
\text { PSF, the more likely it is to be externally owned, ceteris paribus }\end{array}$ & $\begin{array}{l}\text { Dow and Putterman (2000); Fama and } \\
\text { Jensen (1983a); Morrison and } \\
\text { Wilhelm (2004, 2008); Von } \\
\text { Nordenflycht (2009) }\end{array}$ \\
\hline \multirow[t]{5}{*}{$\begin{array}{l}\text { Culture- } \\
\text { homogeneity of } \\
\text { values and beliefs }\end{array}$} & $\begin{array}{l}\text { Effects on locus of ownership } \\
\text { Hypothesis 5.1: The more heterogeneous the values and beliefs of a } \\
\text { PSF, the more likely it is to be externally owned, ceteris paribus }\end{array}$ & $\begin{array}{l}\text { Alchian and Demsetz (1972); Dow and } \\
\text { Putterman (2000); Morris and } \\
\text { Pinnington (1998); Wilhelm and } \\
\text { Downing (2001) }\end{array}$ \\
\hline & $\begin{array}{l}\text { Effects on decision-making } \\
\text { Hypothesis 5.2a: The more heterogeneous the values and beliefs of a } \\
\text { PSF, the stronger are the effects of the locus of ownership and on } \\
\text { hierarchical decision-making, ceteris paribus }\end{array}$ & $\begin{array}{l}\text { Greenwood and Empson (2003); } \\
\text { Greenwood et al. (1990); Nanda } \\
\text { (2003) }\end{array}$ \\
\hline & $\begin{array}{l}\text { Hypothesis 5.2b: In case of external ownership, increasing } \\
\text { heterogeneity of values and beliefs leads to hierarchical decision- } \\
\text { making, ceteris paribus } \\
\text { Hypothesis 5.2c: In case of internal ownership, increasing } \\
\text { heterogeneity of values and beliefs leads to collegial decision- } \\
\text { making, ceteris paribus, but also to lower organizational stability }\end{array}$ & \\
\hline & $\begin{array}{l}\text { Effects on formalization } \\
\text { Hypothesis } 5.3 \text { : Increasing heterogeneity of values and beliefs leads to } \\
\text { increasing formalization of control rights, ceteris paribus }\end{array}$ & $\begin{array}{l}\text { Benham and Keefer (1991); Mintzberg } \\
\text { (1979); Ouchi (1980) }\end{array}$ \\
\hline & $\begin{array}{l}\text { Effects on the remuneration system } \\
\text { Hypothesis 5.4: Increasing heterogeneity of values and beliefs leads to } \\
\text { less use of lockstep remuneration and thus more eat-what-you-kill or } \\
\text { scorecard remuneration, ceteris paribus }\end{array}$ & $\begin{array}{l}\text { Alt (2006); Alchian and Demsetz } \\
\text { (1972); Gilson and Mnookin (1985) }\end{array}$ \\
\hline
\end{tabular}


Table 1 continued

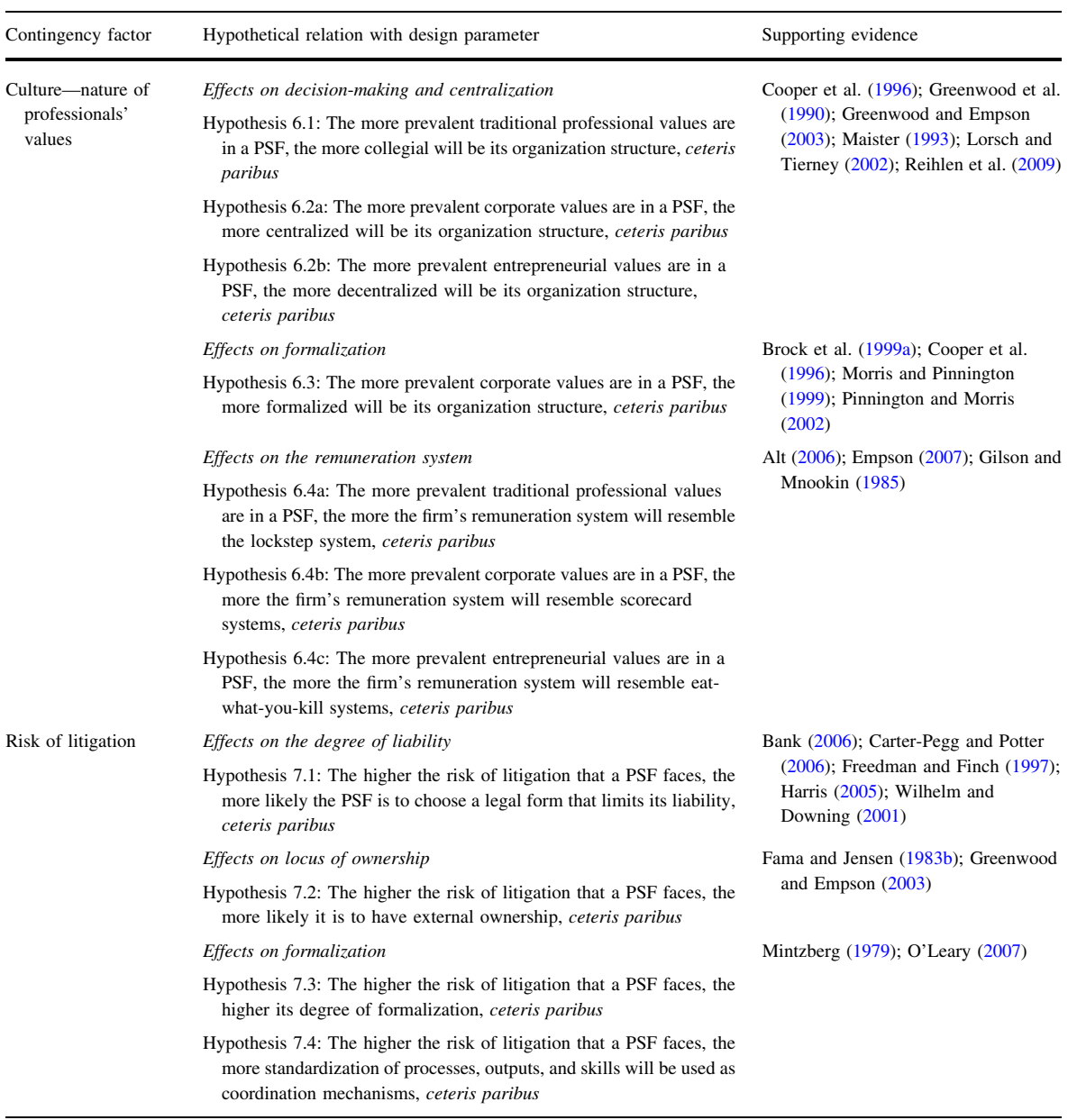

services, most steps necessary for service provision can be well determined in advance and, because of their standardized, routine nature, can also be easily monitored. A scorecard remuneration system that relies on detailed measures of individual behavior should more likely be implemented in such PSFs than in firms that deliver highly customized services, in which a lockstep system may be the only feasible remuneration system if service provision requires strong team production (also see Alchian and Demsetz 1972). Moreover, we suggest that firms providing customized services make more use of up-or-out promotion systems than firms providing commodity services. As Levin and Tadelis (2005) argue, up-or-out acts as a quality signal used when clients find it difficult to estimate service quality in advance, especially when services are customized and novel. 


\subsection{Service diversification}

The demands of global clients for integrated service providers, the declining profitability of the core audit services, and the competitive advantage of existing client relationships in auditing have been cited as reasons for service diversification (Aharoni 1999; Malhotra et al. 2006; Rose and Hinings 1999). Large advertising firms have also increased the scope of their services to include public relations, strategic marketing consulting, and market research (Grabher 2001; von Nordenflycht 2007). In a similar fashion, several large consulting firms have pursued the strategy of providing integrated management and IT consulting services and have expanded into IT systems integration and outsourcing services (e.g., Accenture/ Andersen Consulting, see DeLong 2003). However, while most of the PSF archetype literature focuses on diversification across professional boundaries (e.g., Brock et al. 2007; Greenwood et al. 2002; Rose and Hinings 1999), and this evidently constitutes the highest degree of service diversification, we include various forms of diversification within one profession or industry in our definition of this contingency factor. As many studies have shown, service diversification increases specialization and decentralization (Mintzberg 1979: 380-430; Williamson 1975: 132-154). Moreover, a specialized firm that offers diversified services will find extensive collegial control at the firm level difficult. The reason is that few professionals will have the necessary knowledge, or interest, to participate efficiently in decisions covering diverse areas of expertise (Greenwood and Empson 2003). We, therefore, argue that more diversified PSFs are more likely to apply hierarchical, centralized governance structures. Furthermore, we contend that the more diversified a firm's services are, the more likely it is that some services will be inherently more profitable than others. Sherer (2007) discusses the constraining effect lockstep remuneration has on the diversification of law firms into regions that command lower billing rates, using the US law firms Baker and McKenzie (eatwhat-you-kill) and Cleary Gottlieb (lockstep) as examples. An example outside the legal profession is the declining profitability of accounting services, which was a key reason for accounting firms to expand into consulting services (Koza and Lewin 1999). Under such circumstances, a pure lockstep system is more difficult to sustain across different services.

\subsection{Firm size}

The size of a PSF measured by the number of professionals depends to some extent on the existence of economies of scale or scope. It is sometimes assumed that PSFs do not exhibit strong economies of scale and may even experience diseconomies of scale (Løwendahl 2005). While economies of scale will be less obvious than in manufacturing firms, technological innovations such as those described in Morrison and Wilhelm (2008) may impose significant minimum efficient scales on PSFs. The use of expensive assets such as access to specialized databases tends to impose scale economies on a firm. More importantly, PSFs may increase in size due to assumed benefits of offering a larger scope of services. There are a number of relevant effects: First, the incentive of internal ownership to reduce shirking in service 
delivery (Alchian and Demsetz 1972), to engage in mutual consulting, bonding and monitoring (Fama and Jensen 1983a), as well as to provide mentoring to junior professionals (Morrison and Wilhelm 2004), declines with increasing firm size. Second, this argument can in principle be extended to the degree of liability. As long as a firm is small enough to allow effective monitoring among internal owners, unlimited liability provides a very strong incentive to engage in such activities. As the firm size increases, however, the incentive benefits of unlimited liability will be quickly outweighed by the costs and risks associated with it. Third, as previous studies have shown, larger PSFs are more specialized, decentralized, and apply hierarchical decision-making, and are more likely to formalize procedures such as operating rules and personnel regulations (Brown et al. 1996; Graubner 2006; Greenwood et al. 1993; Greenwood and Empson 2003; Greenwood et al. 2010).

\subsection{Capital intensity}

PSFs are usually thought not to be capital intensive (Greenwood and Empson 2003; von Nordenflycht 2010), since they mainly depend on "assets that go down the elevator each night". However, as the development of the investment banking industry has shown (Augar 2000; Morrison and Wilhelm 2008), some professional industries have become very capital intensive in recent decades. Access to capital may also provide competitive advantage in industries in which service provision itself has not become very capital intensive, such as the advertising industry (see von Nordenflycht 2009 for an explanation of the emergence of large advertising conglomerates). Finally, firms in the accounting and consulting industry may need significant financial resources to pay for information technology (Greenwood and Empson 2003). As "monitoring and work incentives" as well as "investment, wealth, and diversification" theories (Dow and Putterman 2000; Fama and Jensen 1983b) and illustrative evidence from the advertising industry (von Nordenflycht 2009) suggest, more capital-intensive PSFs are more likely to be externally owned.

\subsection{Firm culture}

Culture conceived as shared key values and beliefs (Smirchich 1983) or shared interpretative schemes (e.g., Cooper et al. 1996; Empson and Chapman 2006; Greenwood et al. 1990) has been widely discussed in the PSF literature. In our analysis, we focus on two specific aspects of a PSF's culture-the degree of homogeneity and the nature of a firm's culture. Homogeneous values and beliefs correspond to a single, strong firm culture, whereas heterogeneous values point to a weak overall culture, or a set of rival subcultures. Greenwood and Empson (2003) argue that organizational homogeneity facilitates building consensus among professionals, i.e. facilitates a collegial, decentralized governance structure. They contend that "where there are different sets of values, however, consensus-based approaches and knowledge sharing are more difficult to sustain" (p. 923) and conclude that the partnership form of governance becomes less efficient relative to public corporations as heterogeneity increases. Also, a strong culture like a clan lacks "[...] the explicit rules of the bureaucracy" (Ouchi 1979, 838) and, therefore, 
uses a set of homogeneous values and beliefs as a substitute for formal and bureaucratic modes of control (Mintzberg 1983; Ouchi 1980). In addition, Gilson and Mnookin's (1985) study on law firm remuneration systems suggests that increasing heterogeneity of values and beliefs makes it more likely that firms will use eat-what-you-kill or scorecard instead of lockstep remuneration.

Second, we suggest that the nature of the firm culture affects organizational governance. Two sets of values, which we call "traditional" and "commercial" professional values, are usually juxtaposed. Traditional professional values emphasize the role of the professional as a social trustee (Brint 1994). Professional norms and self-regulating professional institutions are seen as means to prevent professionals from exploiting the knowledge advantage they enjoy over their clients. A change from the traditional professional values to more business-oriented, "commercial" values has been observed along with organizational change in PSFs to more "corporate" forms of governance (e.g., Cooper et al. 1996; Suddaby et al. 2009). This was accompanied by a changing definition of professionalism. Commercial professional values are based on the notion of expertise, rather than public service (Brint 1994; Greenwood 2007). A PSF is regarded as a profit-oriented business selling superior expertise to its clients. We would like to differentiate the notion of commercial professional values, because commercialization need not lead to a more "corporate" way of governance, organization, and management. Instead, we contend that commercialization can either lead to a more "corporate" or to an "entrepreneurial" way of governance. We suggest that the values of professionals can be differentiated accordingly, by splitting the commercial, i.e. non-traditional professional values into corporate and entrepreneurial values. While both are motivated by profitability and growth, professionals with entrepreneurial values favor personal autonomy (for their individual commercial gain rather than altruistic professional purposes) and thus oppose the formalization and standardization usually associated with becoming more "corporate" (Empson and Chapman 2006). The nature of values, as we suggest, affects the structure as well as the choice of remuneration system. Traditional professional values foster collegial structures (Greenwood and Empson 2003; Lorsch and Tierney 2002) and a lockstep remuneration system. More prevalent corporate values in a PSF increases the adoption of centralized and formalized structures as well as a remuneration system that will resemble a scorecard system (Alt 2006; Cooper et al. 1996). Finally, entrepreneurial values facilitate decentralized structures and eat-what-you-kill systems (Maister 1993).

\subsection{Risk of litigation}

The risk of litigation refers to the risk of PSFs being sued, usually by their clients over the quality of work delivered. Accounting firms' increasing size as well as the wealth of their personally liable partners had made them attractive litigation targets, with litigation costs among the Big Six accounting firms reaching US $\$ 35,000$ per partner per year in 1998 (Greenwood and Empson 2003). While many PSFs in other professional industries, such as management consulting firms and advertising agencies chose to incorporate, accounting and law firms often remained 
partnerships, but many chose to convert to LLPs in the jurisdictions where this was permitted (Carter-Pegg and Potter 2006; Freedman and Finch 1997; Harris 2005).

The risk of litigation that a PSF faces varies among the different professional industries. For example, it is often more difficult for clients to perceive the quality of management consulting services than that of auditing services, even ex post. Yet the key difference lies in their ability to prove the PSF's responsibility for inadequate quality. Audits are fairly standardized services that can basically be scrutinized for correctness. Management consulting services, on the other hand, often require both a greater degree of discretion on the professional's part and a greater involvement of the client in the delivery of the service, making it more difficult to prove negligence or malpractice. Service commoditization will generally increase clients' ability to observe service quality and the PSF's responsibility, thus raising the risk of litigation. The risk of litigation also increases if PSFs do not handle potential conflicts of interest appropriately (see Mehran and Stulz 2007, for a review of the empirical literature on this conflict of interest).

We can now draw a number of implications. First, the higher the risk of litigation that a PSF faces, the more likely the PSF is to choose a legal form that will limit its liability. Following Greenwood and Empson (2003) we can also suggest that a rising risk of litigation will eventually result in change of ownership locus (see Fama and Jensen 1983b). Second, to address the root cause of litigation, i.e. inadequate service quality or a conflict of interest, firms will eventually use more standardized recruiting and training processes intended to lower the chances of having insufficiently qualified professionals; this will lead to standardization of skills, which in itself serves to improve service quality. Furthermore, the establishment of rules constraining behavior that may increase the risk of litigation needs to take place on a hierarchical level "above" the one where such behavior is likely to occur, most likely on the level of the firm, rather than that of subsidiary organizational units, leading to centralization.

\section{Configurations of PSF governance}

In the preceding sections, we defined the key dimensions along which the governance of PSFs varies and identified factors that account for such variation. The results are several dozen cause and effect relationships that link individual causal factors with particular governance dimensions. We thus systematically collected theoretical and empirical evidence on the interdependencies that exist among contingency factors and governance design parameters as far as they have been subject to previous research. In this section, we take these interdependencies explicitly into account by integrating individual cause and effect relationships into ideal types, the configurations of PSF governance. By synthesizing previous research into configurations, we offer richer descriptions of PSF governance than a collection of bivariate relationships could achieve (Meyer et al. 1993; Wolf 2000). We describe governance characteristics and conditions of each of these configurations and use illustrations from well-known PSFs that closely resemble them (see Table 2). 
Table 2 PSF governance configurations

\begin{tabular}{|c|c|c|c|c|}
\hline & $\begin{array}{l}\text { Founder- } \\
\text { dominated } \\
\text { governance }\end{array}$ & $\begin{array}{l}\text { Collegial } \\
\text { governance }\end{array}$ & $\begin{array}{l}\text { Managerial } \\
\text { governance }\end{array}$ & $\begin{array}{l}\text { Entrepreneurial } \\
\text { governance }\end{array}$ \\
\hline \multicolumn{5}{|c|}{ Governance dimensions } \\
\hline $\begin{array}{l}\text { Locus of } \\
\text { ownership }\end{array}$ & $\begin{array}{l}\text { Internal, } \\
\text { concentrated }\end{array}$ & Internal & External & Not specified \\
\hline Degree of liability & Not specified & Unlimited & Limited & Limited \\
\hline $\begin{array}{l}\text { Specialization of } \\
\text { control rights }\end{array}$ & Unspecialized & Unspecialized & Specialized & Specialized \\
\hline Centralization & Centralized & Centralized & $\begin{array}{l}\text { Moderately } \\
\text { decentralized }\end{array}$ & Decentralized \\
\hline Decision-making & Hierarchical & Collegial & Hierarchical & Hierarchical \\
\hline Formalization & Not formalized & Not formalized & Formalized & Not formalized \\
\hline $\begin{array}{l}\text { Remuneration } \\
\text { system }\end{array}$ & Informal/closed & Lockstep & $\begin{array}{l}\text { Conting. income } \\
\text { low; scorecard }\end{array}$ & $\begin{array}{l}\text { Eat-what-you- } \\
\text { kill }\end{array}$ \\
\hline Promotion system & $\begin{array}{r}\text { Permanent } \\
\text { positions }\end{array}$ & Up-or-out & $\begin{array}{r}\text { Permanent } \\
\text { positions }\end{array}$ & Not specified \\
\hline \multicolumn{5}{|l|}{ Contingency factors } \\
\hline $\begin{array}{l}\text { Service } \\
\text { commoditization }\end{array}$ & Customized & Customized & Commoditized & Varying degree \\
\hline $\begin{array}{l}\text { Service } \\
\text { diversification }\end{array}$ & Non-diversified & Non-diversified & Diversified & Diversified \\
\hline Firm size & Small & Small & Large & Medium-large \\
\hline Capital intensity & Low & Low & High & Low \\
\hline Values and beliefs & $\begin{array}{l}\text { Homogeneous } \\
\text { among founders }\end{array}$ & Homogeneous & Heterogeneous & Heterogeneous \\
\hline $\begin{array}{l}\text { Nature of } \\
\text { professionals' } \\
\text { values }\end{array}$ & $\begin{array}{l}\text { Entrepreneurial or } \\
\text { traditional }\end{array}$ & $\begin{array}{l}\text { Traditional or } \\
\text { entrepreneurial }\end{array}$ & Corporate & Entrepreneurial \\
\hline Risk of litigation & Not specified & Low & High & Low-medium \\
\hline
\end{tabular}

\subsection{Founder-dominated governance}

\subsubsection{Governance characteristics}

The founder-dominated governance configuration describes characteristics shared by many young, small firms. Its dominant governance theme is centered around leadership. While the essence of the configuration is not unique to PSFs, the configuration is important in describing many PSFs which have a charismatic founder or a small group of senior professionals that is vital to the firm's success and effectively governs the firm.

The founder-dominated governance configuration is characterized by internal ownership, albeit more concentrated in the hands of one or a few professionals. Bain \& Company, a management consulting firm, exemplified the founder-dominated governance configuration in several respects until it reorganized its ownership and 
control structure in 1990. Until 1985 ownership of Bain \& Company had been restricted to a "founding group" consisting of Bill Bain and seven senior professionals. Ownership was thus internal and highly concentrated. In 1985, the firm was incorporated and an employee stock ownership plan (ESOP) was launched. During the two following years, the founding group sold $30 \%$ of their equity stake to the ESOP for $\$ 200$ million, loading the firm with debt. The firm's ownership structure remained highly concentrated until it was restructured in 1990 (Williamson and Yoshino 1994). In the German context, the early days of consulting firms such as Simon, Kucher and Partners or the engineering consulting firm Miebach Logistics until the founder resigned from the board, or small boutique corporate law firms like Glade, Michel and Wirtz (see Günther 2012) come close to our founderdominated governance model.

In the same way as ownership, control rights are largely concentrated in the same professional or professionals. The distribution of control rights is thus both centralized and follows hierarchical decision-making. As a result of the inherent complexity of professional work, control rights may be more widely distributed than in the typical entrepreneurial, owner-managed non-professional firm (Blau 1984), but still the founder-dominated configuration marks the centralized ends of the spectra of hierarchical decision-making and distribution of control rights.

Before the firm's restructuring, control rights at Bain \& Company had been highly centralized in the person of Bill Bain. For example, partner remuneration was not determined according to any transparent remuneration system, but instead was at the discretion of Bill Bain. A former partner referred to the partnership agreement as "not a bill of rights, but the rights of Bill" (Gallese 1989).

The founder-dominated configuration is "characterized, above all, by what it is not - elaborated. Typically, it has [...] a loose division of labor, minimal differentiation among its units, and a small managerial hierarchy. Little of its behavior is formalized" (Mintzberg 1979: 306). The control rights in this configuration are thus unspecialized and not formalized. Power is centralized at the top and the small size of such firms means little formalization or standardization is needed or feasible.

According to its low degree of formalization and standardization, the founderdominated governance configuration has neither an elaborate nor a strongly formalized remuneration system. If ownership and control rights are sufficiently concentrated, contingent remuneration is likely to be determined informally by the controlling group or individual, as had been the case with Bain \& Company. Unless the nature of the services delivered allows easy to administer performance-related remuneration, remuneration is likely to be explicitly or implicitly based on lockstep, with the (presumably more senior) controlling group or individual earning substantially more than other professionals.

The founder-dominated configuration offers professionals permanent positions rather than using an up-or-out promotion system. This may be in part because firms are often too small to make an up-or-out system feasible, but also because of the disproportionate importance of the controlling group or individual for the firm, which makes the firm less prone to other professionals "grabbing clients and leaving" (see Rebitzer and Taylor 2007 for a discussion of this risk), if they have been in permanent positions. 


\subsubsection{Conditions}

The founder-dominated configuration is typically found in small firms. As firms grow and get older, the influence of the founding group is bound to decline. Also, the decision-making style, which is ad hoc, but both hierarchical and centralized, does not correspond to the requirements of large firms. Other aspects of firm strategy such as the degree of service customization may vary in the founderdominated configuration. Firms following this configuration are less likely to offer diversified services, since the human capital of the founding group should be specialized in some respect in order for the firm to have any competitive advantage over larger, established firms. Also, this configuration is associated with customized, rather than commoditized services. Service commoditization generally leads to specialization and formalization, which are aspects of the managerial configuration rather than the founder-dominated configuration. A small, founder-dominated firm should find it more difficult to compete with larger, established firms in commoditized, rather than customized services.

While small, founder-dominated firms may be less willing to operate in an environment with a high risk of litigation, this risk may vary widely among firms and is not considered an important factor regarding the founder-dominated governance configuration. Unless a firm stays small and manages to transfer the special human capital from the controlling group to an eventual successor, the founder-dominated configuration is typically a transitory governance model. Many successful firms will simply outgrow this configuration.

\subsection{Collegial governance}

\subsubsection{Governance characteristics}

Collegial governance is founded on the idea of professional autonomy and selfgovernance. These principles are best accomplished by internal ownership, in which partners share collegial control over decision-making. Some firms closely resembling the configuration, like the New York law firm Wachtell, Lipton, Rosen and Katz, are still general partnerships with unlimited liability, whereas others have switched to limited liability. Regarding its legal form, the collegial configuration thus matches the "professional partnership" archetype, although firms operating as private corporations may also closely resemble our configuration.

Decision-making follows a collegial structure, which allows professionals to participate widely in important decisions, striving for consensus where possible. However, control rights are centralized, resulting in a "one firm" firm, in which most control rights reside at the level of the firm, rather than at some subordinate organizational level.

The collegial governance configuration is characterized by a less specialized governance structure. Wachtell Lipton, for instance, is loosely organized into eight practice areas, but provides its services through task forces that are staffed ad hoc from several practice areas, depending on the requirements of the individual case. Having only one office despite an increasing amount of work involving non-US 
clients, it is not specialized by region. Interestingly, Wachtell Lipton briefly experimented with a London office, but closed it again. Following the rise of London as a financial center, opening a permanent London office has been discussed numerous times (Berris and Byrne 2007), but so far the firm has stuck to its guideline of not having branch offices preferring to work with foreign referral firms if necessary (Illman 2007).

Wachtell Lipton epitomizes the collegial governance configuration in the minimal formalization of control rights. Despite being a prestigious firm of more than 80 partners, Wachtell Lipton has followed its guiding principle that "there is no partnership agreement—only a handshake among friends" (Lipton 1990, as cited by Starbuck 1993, 908). The introduction of the executive committee has somewhat formalized decision-making, but the firm has maintained its aversion to bureaucracy (Starbuck 1993). A collegial and informal work environment facilitates the selforganization of work. At Wachtell Lipton, this work environment is partly cultivated by the task forces that deal with particular cases. As Lipton (1990) explains, "the task forces overlap with a particular lawyer leading one or more and assisting on one or more" (cited by Starbuck 1993, 908).

Regarding the systems for managing professionals, the collegial governance configuration corresponds to the professional partnership archetype. Remuneration is based on the lockstep system: promotion on the up-or-out system. Both systems can be found at Wachtell Lipton. The firm follows a pure lockstep system, with no regard to billed hours, client contact, or management functions. In addition to the lockstep partner remuneration, the year-end bonus of associates and support staff is determined only by firm performance, not by individual performance (Lorsch and Graff 1995). Partners at the firm value the lockstep system because it fosters cooperation and reinforces the firm's egalitarian culture (Starbuck 1993). Regarding the promotion system, the founders of Wachtell Lipton decided that "no lawyer would be hired or retained unless they expected him to become a partner" (Starbuck 1993, 905). The firm has followed this principle, refusing to introduce permanent positions like permanent associates or non-equity partners, which have become common in many other law firms (for more on this see Smets et al. 2012).

\subsubsection{Conditions}

The collegial governance configuration occurs in firms that offer non-diversified, highly customized services. In contrast to other PSFs, firms following this configuration deliberately focus on a narrow set of services for which they have special expertise and often gain a strong reputation. In their area of expertise, they are often at the forefront in developing innovative services that are customized to the requirements of individual clients. In order to reinforce their reputation as the leading PSF for their area of expertise, these firms often leave the more routine services to competitors with a more diversified service portfolio. One of the guiding principles (Lipton 1990, as cited by Illman 2007, 25) of Wachtell Lipton is that "the practice of the firm is to focus on a limited number of interesting and difficult specialties. The firm declines a significant number of matters for which its services are sought". As a result of their pursuit of innovative, unique problems to solve in a 
comparatively narrow area of expertise, these firms are often rather small, "boutique" firms.

Their non-diversified, highly customized service offering, together with their small size, largely determines the governance characteristics of these elite firms. For example, a non-diversified service portfolio is the strongest factor favoring an unspecialized, centralized distribution of control rights. Offering highly customized services also call for little organizational specialization, because the lack of repetitive tasks reduces the potential efficiency gains of a high division of labor. Furthermore, being small favors both centralization and lack of specialization. All three elements of firm strategy consistently favor a collegial distribution of control rights and the use of lockstep remuneration.

The collegial governance configuration is most feasible if the professionals share common values and beliefs. Homogeneous values facilitate internal ownership, an organization structure which is centralized and not formalized, whereas heterogeneous values impede these governance characteristics.

The collegial configuration can be characterized by traditional professional values or entrepreneurial values, but not by corporate values. Both conform to aspects of the configuration's governance characteristics, with traditional values providing the even better fit: Entrepreneurial values favor a low degree of formalization. Traditional values in addition favor collegial decision-making structures, and lockstep remuneration. Corporate values, on the other hand, favor different characteristics, such as hierarchical organization structures, formalization, and a remuneration system based on individual performance characteristics.

The collegial governance configuration is most likely to occur in PSFs that, in addition to the above factors, operate in an environment that poses a low risk of litigation for the PSF.

\subsection{Managerial governance}

\subsubsection{Governance characteristics}

Today, aspects of the managerial governance configuration can be observed in many PSFs, such as major law firms like Baker and McKenzie, multinational accounting firms like Ernst and Young or KPMG, or large IT consulting firms such as Gapgemini or Accenture. The managerial governance configuration differs profoundly from the previously discussed configuration. Principles of professional autonomy and selfgovernance are replaced with managerial control, formalization, and a more hierarchical decision-making style. The changes in governance from a collegial towards a managerial governance system have been analyzed in longitudinal studies. In the accounting industry, Deutsche Treuhand Gesellschaft - a founding member of KPMG (Reihlen et al. 2009) — and Arthur Andersen (Alt 2006) illustrate this transformation from a collegial to a managerial governance.

Firms closely following the managerial governance configuration are typically externally owned and have limited liability. While the major accounting firms are largely excluded from external ownership, they have lobbied intensely for the LLP and have changed their legal form to that of the LLP where possible. 
Capgemini SA, a French consulting firm, offering a broad range of management and technology consulting, as well as outsourcing services, is a good example of the managerial configuration. The managerial configuration applies a hierarchical mode of decision-making coupled with a degree of decentralization. Capgemini exemplifies both hierarchical decision-making as well as the moderately decentralized organization structure. In its 2007 annual report (Capgemini 2008), the firm states: "The principle of subsidiarity is .. paramount, meaning that decisions are to be made as closely as possible to their point of application, and only forwarded to a higher level when they might have an impact on other units besides the one directly concerned". Nonetheless, the centralized Group Management at Capgemini retains a significant degree of control and sets rules and standards for the operating units, which "entails strict compliance with a certain number of rules relating to finance, human resources, sales strategy, marketing and communication and legal affairs" (Capgemini 2008). Managerial governance is further emphasized in transnational PSF such as the Big Four accounting firms, which have implemented regionally integrated partnerships. Under these conditions, firms still remain legally a partnership, but partners no longer have voting rights on strategic matters in the partner meetings, as these decisions are now made by a body of elected executives established at the area governance level (Klimkeit and Reihlen 2012).

The managerial configuration is further characterized by a high degree of specialization and formalization. The formalization of processes and outputs in the managerial configuration are best exemplified in Capgemini's " $\mathrm{I}^{3}$ " transformation

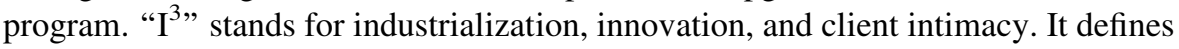
and implements firm-wide standards such as project delivery methodologies (Capgemini 2008, 63).

Owing to the standardized nature of the services, the work of individual professionals can be controlled comparatively easily, and contingent remuneration is thus less needed in the managerial governance configuration than in other PSFs. Still these firms will rarely forgo contingent remuneration completely, at least for their senior professionals. In these cases, scorecard remuneration will be used primarily. As can be expected for a global, highly diversified PSF, Capgemini's remuneration system "is based on common principles, applied in a decentralized way and tailored to local job market conditions and regulations [...] to reward performance with a remuneration model that is motivating yet flexible" (Capgemini $2009 \mathrm{~b}, 33$ ). The managerial configuration is characterized by permanent positions. Like most other IT consulting firms, Capgemini does not have an up-or-out promotion system.

\subsubsection{Conditions}

As the high degree of formalization suggests, the managerial configuration occurs in firms offering primarily commoditized services. Capgemini offers a wide range of services, some more commoditized than others. Still, commoditized services may be considered the focus of the firm's service portfolio (Capgemini 2009a). Furthermore, Capgemini's service offering is highly diversified and characterized by a large firm size. Capgemini has developed into one of the largest IT-services firms 
worldwide. The large number of acquisitions that the firm made indicates that a large firm size is indeed a strategic goal of the firm, to utilize economies of scale and scope in the provision of services to its increasingly global clients. Taken together, the three aspects of firm strategy (service commoditization, diversification, and size) specified in our contingency factors offer a consistent explanation for the governance characteristics of the managerial configuration. For example, all three factors point to a specialized, hierarchical distribution of control rights, as well as to the use of individual performance characteristics in the remuneration system.

Managerial governance occurs in firms that depend primarily on capital-intensive assets suggesting external ownership of the firm. The use of formalized organization structure and internally developed processes, methods, and tools, such as Rightshore $^{\mathrm{TM}}$ or OTACE by Capgemini's professionals make individual expert knowledge more easily replaceable than that of other PSFs, such as the elite law firm Wachtell, Lipton, Rosen and Katz.

The managerial configuration is found in firms with heterogeneous rather than homogeneous values and beliefs, as heterogeneous values encourage the adoption of a formalized, decentralized, and, in connection with external ownership, hierarchical distribution of control rights. Where values among professionals differ significantly, these more "corporate" governance characteristics lead to greater efficiency in decision-making under conditions of cultural diversity. Furthermore, corporate values are likely to be the predominant values, as they form a consistent interpretive scheme of the governance characteristics of the managerial configuration.

The managerial governance typically occurs in firms that face a high risk of litigation, not least because low service quality is more easily detected in commoditized services than in highly customized services, and thus becomes the cause of litigation. The change of governance in the large accounting firms towards the managerial configuration can be interpreted in part as a reaction to the risk of litigation by clients, which was perceived in the industry as having increased significantly (Freedman and Finch 1997). The development of the OTACE qualitycontrol system by Capgemini can be interpreted as a preventive measure against disputes with clients regarding service quality.

\subsection{Entrepreneurial governance}

\subsubsection{Governance characteristics}

Greenberg Traurig, LLP, a fast-growing Miami-based law firm, epitomizes the entrepreneurial governance configuration in many respects. Like Wachtell, Lipton, Rosen and Katz, the exemplar of the collegial configuration, Greenberg Traurig is fairly young for a well-known law firm, having been founded only in 1967. Yet the two firms could not be more different. In 1997, Cesar Alvarez, who had joined the firm in 1973, took over as CEO. Under his leadership, the firm expanded rapidly, both nationally and internationally. At the end of 2008, the firm had about 1,800 lawyers in 32 offices, including two in Europe and two in Asia. Governance of this configuration is founded on the "attempt to maximize the entrepreneurialism of 
their members, by creating the maximum possible degree of individual autonomy. ... The benefits (and limitations) of firmwide consistency (in services, in markets, and in approach) are sacrificed to capture the benefits of .. market opportunities" (Maister 1993, 322). The emergence of entrepreneurial governance has been reported in diverse professional settings (Clark 1998; Maister 1993; Wissema 2009). Interestingly, the entrepreneurial governance model has also been observed and subject to intensive debates in the higher education field in Germany (Reihlen and Wenzlaff 2014) and around the world (Clark 1998).

Like the managerial governance configuration described in the previous section, the entrepreneurial governance combines a hierarchical decision-making system with a decentralized distribution of control rights. The entrepreneurial configuration is in fact more decentralized than its managerial counterpart. While both configurations also follow commercial, rather than traditional, professional values, their governance characteristics differ significantly along several dimensions.

The entrepreneurial governance configuration is not characterized by a particular locus of ownership. While Greenberg Traurig as a LLP is internally owned, there are externally owned PSFs whose governance characteristics are similar to the entrepreneurial structure, such as the large advertising conglomerates like WPP. Also, the internal ownership of Greenberg Traurig is in part due to legal restrictions, as law-firm ownership in the US is restricted to lawyers. At any rate, the entrepreneurial governance is characterized by limited liability.

The entrepreneurial governance configuration is characterized by a distribution of control rights that is at the same time hierarchical and somewhat decentralized. At Greenberg Traurig, power at the firm level is centralized at the CEO office, with the 14-person executive committee having more of an advisory role. Committees are disdained as slowing down decision-making. The CEO can decide on a wide range of issues, such as firm-expansion strategy, hiring of senior professionals, or even partner compensation, without consulting the wider partnership of the firm (Kolz 2007). At the same time, the individual partners have a high degree of autonomy in providing their services. In many PSFs, expansion into new practice areas is cautious and follows lengthy discussions within the partnership. At Greenberg Traurig, partners act as entrepreneurs with a degree of autonomy (Kolz 2007).

Also, partners are allowed to individually negotiate their hourly rates with clients if this helps to increase total business, a practice that is discouraged or even prohibited in many other law firms (Kolz 2007). Partly as a result of such autonomy, the services offered by firms following the entrepreneurial governance configuration tend to be highly diversified, resulting in a specialized organization structure. At the end of 2008, Greenberg Traurig listed 52 (partially overlapping) practice areas and 20 client industries on their website.

The entrepreneurial governance configuration is characterized by a low degree of formalization. There are few rules and regulations. Not only organizational units such as practice areas, but also individual senior professionals are controlled mainly on a financial basis. Low formalization and strong autonomy regarding delivery of services is offset by strict financial discipline and formalized business planning. At Greenberg Traurig, the annual partner reviews are said to resemble business planning meetings. Cesar Alvarez, the CEO, receives detailed daily reports 
regarding the firm's billing rates, hours billed, and other financial performance indicators. Attention is focused on those partners that do not meet their agreed business targets (Kolz 2007).

Owing to the individualistic nature of the governance configuration, coordination needs are somewhat lower than at other PSFs. In accordance with the combination of a strong focus on financial success but great autonomy of professionals in other matters, remuneration in entrepreneurial governance follows an eat-what-you-kill system. At Greenberg Traurig, bonuses, which constitute a large part of partners' total income, are mainly based on individual business performance. However, the compensation system is closed, meaning that the CEO office ultimately decides on the compensation of individual partners and does not disclose it to the partner group. This allows the firm to attract senior lateral hires with a high level of compensation without upsetting existing professionals. Also, reduced performance of individual professionals is less visible to their peers compared with an open system (Jones 2006; Kolz 2007). On the other hand, this strongly enhances the power of the CEO. As a result, Greenberg Traurig may, therefore, be more centralized than other firms following the entrepreneurial governance configuration.

\subsubsection{Conditions}

The entrepreneurial governance configuration does not depend on a particular degree of service commoditization. In fact, owing to the high degree of service diversification, a PSF employing this governance configuration is likely to offer services of varying degrees of commoditization. The autonomy professionals enjoy in offering new kinds of services makes it unlikely that such a PSF would offer only highly customized or highly commoditized services. With its more than 50 practice areas, Greenberg Traurig has a highly diversified range of services. Also, its services vary significantly in their degree of commoditization. Entrepreneurial governance is likely to be found in large PSFs, not least because firms following this configuration often put a strong emphasis on growth. Greenberg Traurig has grown significantly throughout its existence, with average annual growth rates between 10 and $20 \%$. Together, large firm size and strong service diversification point to several governance characteristics that distinguish the entrepreneurial configuration from the collegial configuration, such as a high degree of specialization, decentralization, and formalization.

The entrepreneurial nature of this configuration allows professionals to utilize their personal networks and reputations without being restricted by firm rules. Most PSFs that accept lateral hires welcome professionals with strong client relationships and personal reputations. At firms following an entrepreneurial governance model, the eat-what-you-kill remuneration system allows these professionals to profit directly from their human capital. The strong growth of Greenberg Traurig derived in large part from its ability to attract senior professionals who had already developed strong reputations and valuable client relationships.

Professionals at firms that follow the entrepreneurial model are likely to have somewhat heterogeneous values and beliefs as a result of the diversity of services they deliver. More important, however, are their shared entrepreneurial values and 
the relative absence of traditional professional values. As in firms following the managerial configuration, professionals see themselves as experts helping clients to reach their business objectives, rather than as social trustees delivering a public service. Moreover, professionals have their own individual business objectives.

Finally, firms following the entrepreneurial governance configuration should generally have a low to medium risk of litigation. Unless this risk is very low, firms will usually opt for limited liability but will not adapt other governance characteristics. A high risk of litigation would call for formalization and standardization, leading firms closer to the managerial governance configuration. However, the combination of an entrepreneurial, commercial firm culture and a decentralized organization with few rules or standards can itself increase the risk of litigation.

\section{Discussion}

This article contributes to the literature on PSFs by analyzing different forms of governance. We chose to follow configuration theory in our approach and developed four ideal types of PSF governance: the founder-dominated, the collegial, the managerial, and the entrepreneurial governance configuration. By analyzing both the PSF literature as well as the relevant general organization studies literature, we identified seven major design parameters of PSF governance and six contingency factors, which influence the governance dimensions. Our study provides a synthesis of the research on PSF governance, which has so far been lacking. In addition, it also facilitates the comparison of governance developments among very different PSFs, whereas previous studies often focused on particular professions, such as law (Morris and Pinnington 1999; Pinnington and Morris 2003) or accounting (Cooper et al. 1996; Greenwood et al. 1990; Lenz and James 2006), or have limited themselves to the study of partnerships (Greenwood et al. 1990; Pinnington and Morris 1996).

\subsection{Comparison of PSF governance and PSF archetypes}

Our study takes a more differentiated approach to the governance of PSFs. By looking at multiple governance dimensions and relating them to numerous contingency factors, this study makes it possible to determine what conditions facilitate or obstruct configurational coherence. By introducing the founderdominated and theorizing on Maister's hunter type, this study adds two empirically important governance types that have no equivalent in the PSF governance literature so far. A comparison of our and the more established organizational archetypes is presented in Table 3.

Furthermore, our governance configurations allow for more precision and distinction in describing each governance form. For instance, there is a discrepancy between the $\mathrm{P}^{2}$ archetype as described by Brock et al. $(1999 \mathrm{a}, 2007)$ and as originally developed by (Greenwood et al. 1990). While both focus on governance aspects close to our collegial governance, the examples used to illustrate the 
Table 3 Governance configurations and related PSF archetypes

\begin{tabular}{|c|c|c|c|}
\hline $\begin{array}{l}\text { Founder- } \\
\text { dominated } \\
\text { Gov. }\end{array}$ & Collegial governance & Managerial governance & $\begin{array}{l}\text { Entrepreneurial } \\
\text { governance }\end{array}$ \\
\hline $\begin{array}{l}\text { PSF } \\
\text { archetypes }\end{array}$ & $\begin{array}{l}\text { Star (Brock et al. } \\
\text { 1999a, 2007) } \\
\text { One-firm firm } \\
\text { (Maister 1993) } \\
\text { Professional } \\
\text { partnership } \\
\text { (Greenwood et al. } \\
\text { 1990) }\end{array}$ & $\begin{array}{l}\text { Global Professional Network (Brock, Powell } \\
\text { and Hinings 1999a; Brock et al. 2007; Lenz } \\
\text { and James 2006) } \\
\text { Managed Professional Business (Cooper et al. } \\
\text { 1996) }\end{array}$ & $\begin{array}{l}\text { Hunter firms } \\
\text { (Maister } \\
\text { 1993) }\end{array}$ \\
\hline
\end{tabular}

archetype differ significantly: The $\mathrm{P}^{2}$ portrayed by Brock et al. (1999a, 2007) focuses on the smallest PSFs such as the "neighbourhood law practice" (Brock et al. 1999a, 226) and even includes solo practitioners. It can thus be regarded as a hybrid between the collegial governance and the founder-dominated configurations.

In contrast, Greenwood et al. (1990) originally developed the $\mathrm{P}^{2}$ archetype looking at large accounting firms that were operating on a national and even international level. In the description of Greenwood, Hinings and Brown and even in the earlier account of Montagna (1968) elements of managerial governance can be identified. As Montagna (1968) states: “.., the formal managerial decisionmaking structure of a Big Eight firm is highly centralized, with a senior partner as 'resident' of the firm and chairman of the executive or managing committee. The committee is composed of partner-directors for each of the firm's major areas of specialization, with lines of authority within each area and for each region of the country. Even though every partner is given personal responsibility over his audit for the client, the system of checks on his work, along with the formal structure, allows the firms to be classified as highly centralized." (p. 141). The professional partnership in the accounting industry can thus be seen as a hybrid between our collegial and the managerial configuration. In recent years, these firms moved much closer to the managerial configuration (Brock et al. 2007; Cooper et al. 1996; Malhotra et al. 2006).

\subsection{Evolution of PSF governance}

Our approach also contributes to explaining the evolution of PSF governance. The development of the large accounting partnerships, for instance, towards the managerial configuration can be explained with the changing conditions that these firms faced. Most notable are the growth in firm size and the increased diversification, both in geographical scope and in the increasing importance of non-accounting services. These changes are well exemplified by a study from Alt (2006). He analyzed organizational changes taking place at Arthur Andersen, one of the "Big Five" accounting firms until its involvement in the Enron scandal, which led to its demise in 2002. Following his analysis, he divides the history of Arthur 
Andersen into four periods. The first period, from 1913 to 1947, is characterized by the dominant role of the firm's founder, Arthur E. Andersen, who was managing director until his death in 1947. During the first period, the firm was managed as a "one-man professional partnership" (Alt 2006, 155) reflecting our founderdominated governance configuration. Andersen's successor Leonard Spacek, who became managing director in 1947, introduced a democratic decision-making style and a fusion of ownership and control among partners. In this second period, the firm expanded significantly and emerged into a professional partnership (Greenwood et al. 1990) with a collegial governance configuration. The retirement of Leonard Spacek as Chairman of the firm in 1973 marks the beginning of the third period (Alt 2006). The rise of IT- and management consulting as new entrepreneurial opportunities of the firm led to service diversification and further growth. Professionals were increasingly specialized and the organizational structure was characterized by increasing centralization, formalization, and remuneration based on individual performance. According to Alt, Arthur Andersen transformed into a "managed professional business" (Cooper et al. 1996) during this period. Referring to our governance configurations, the firm was a hybrid between the collegial and the managerial configuration. The worldwide partner meeting in 1988 marked the beginning of the fourth period of Arthur Andersen according to Alt (2006). The partner meeting was held under the title "profit \& sales" and prepared partners for a stronger focus on clients and business success. In 1992, the $10 \%$ lowest performing partners had to leave the firm. Control was further centralized, replacing the old collegial decision-making style. Also, formalization continued with a focus on business performance turning Arthur Andersen in its fourth period into a "managed business" (Alt 2006), which is reflected in our managerial configuration. The move from the collegial towards the managerial governance configuration, driven by such contingencies as growth in firm size, diversification, and service commoditization, can be observed in other professional sectors as well, such as law firms (e.g., Cooper et al. 1996; Galanter and Palay 1991; Morris and Pinnington 1999), investment banks (Morrison and Wilhelm 2007, 2008), and even in advertising conglomerates such as WPP (Bower 2003).

\subsection{Firm growth and PSF governance}

Our study also opens a new research frontier, which has rather been underexplored-the relation between PSF governance and the firm's growth strategy. Previous research has investigated growth strategies based on knowledge-based innovations resulting in new practice developments (Anand et al. 2007), internationalization (Aharoni 1993), and the exploration of new regional markets (Reihlen et al. 2009), as well as growth opportunities through mergers and acquisitions, and alliances (Kaiser and Ringlstetter 2011). Yet, very little is known on how the governance type impacts the firm's growth strategy. According to configuration theory, organizations strive for consistency between design parameters and contingency factors and the interdependencies among organizational elements create a stable pattern of action resonating around joint themes that reflect the driving character of the firm. As Miller (1996) argues, the organizational imperative 


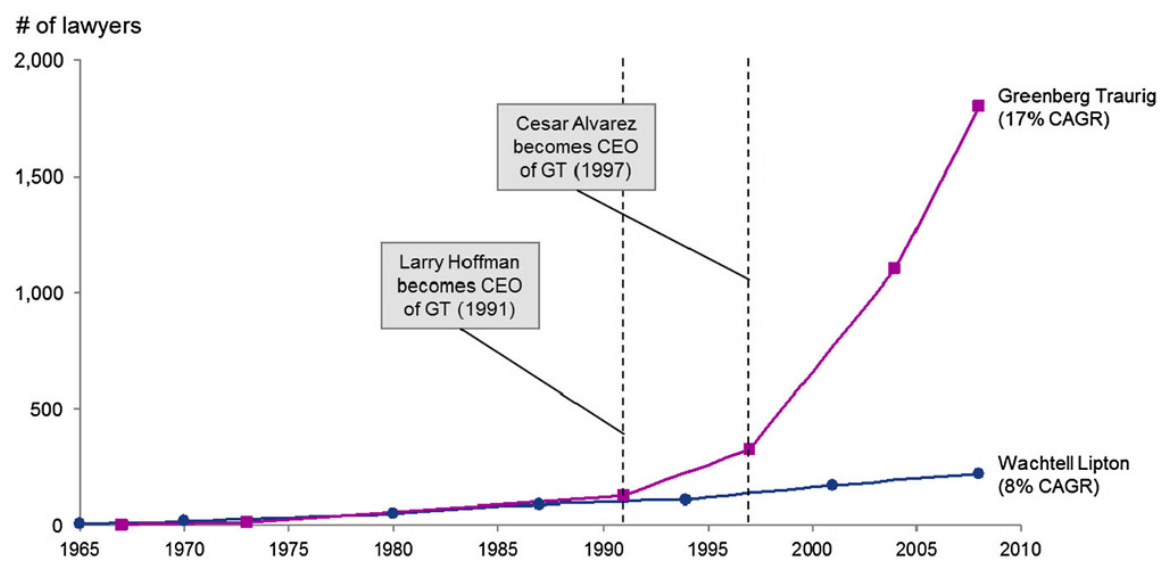

Fig. 3 Comparison of annual growth rates between Greenberg Traurig and Wachtell Lipton. Source: Data gathered from Kolz (2007), http://fundinguniverse.com, company websites http://www.gtlaw.com, website http://www.wlrk.com, and http://www.fundinguniverse.com

or theme-in our case leadership, collegiality, managerial hierarchy, or entrepreneurial growth - has "the most predictive and normative implications, and endows configurations with their stability" (p. 507). Furthermore, the organizational imperative is reinforced through evolutionary selection and retention processes based on existing strategies, structures, and systems (Miller 1996).

We suggest that divergent assumptions about the degree of choice firms have when considering different growth options reflect differences in PSF governance. A first indication of the relation between governance type and its underlying growth pattern is given in Fig. 3, which compares the Compound Annual Growth Rates (CAGR) of two of our illustrative sample firms from the legal professionGreenberg Traurig and Wachtell Lipton.

So, for example, firms with a collegial governance such as Wachtell Lipton follow a "policy of slow growth, careful recruiting of outstanding people, and, with only the rarest of exceptions, no lateral entry" (Lipton 1990, as cited in Illman 2007, 25). A culture with traditional professional values is created by staff which is homegrown (Starbuck 1993, 914) supporting close quality monitoring in its core domain, but also limits expansion into new service domains and regions. The organizational imperative of Wachtell Lipton is further facilitated by its organic governance structure, lockstep remuneration, and an up-or-out promotion system. Furthermore, the small size and slow growth of Wachtell Lipton are also explained by its limitation to innovative cases and the clear avoidance to expand by mergers (Illman 2007). On the contrary, firms with entrepreneurial governance such as Greenberg Traurig emphasize entrepreneurial opportunity seeking and encourage diverse growth strategies such as diversification and internationalization (Kaiser and Ringlstetter 2011). Especially diversification and internationalization have deliberately been avoided by Wachtell Lipton as it would have undermined its homogenous and collegial culture. When Alvarez took over as CEO in 1997 at Greenberg and 
Traurig, he emphasized autonomy of individual professionals combined with a strong focus on profitability and growth aided by a remuneration system and entrepreneurial culture that reinforced this imperative. Greenberg Traurig has, therefore, grown significantly over a period of more than 40 years. In this way, we argue that growth strategies of firms are constrained by previous acceptance of organizational values and practices reflecting the characteristics of the governance configuration. This study suggests that a focus on PSF governance configurations may lead to further insights into processes of organizational growth. If growth strategies and governance models operate in tandem, then future studies investigating this link may provide further insight into the evolutionary patterns of growth and the underlying organizational mechanisms accountable for them.

\section{Limitations and future research}

Following Rorty $(1991,81)$ " $[\mathrm{t}]$ heories and perspectives draw our attention to certain issues; they invite us to punctuate the world in particular ways; they are tools for doing things, rather than mere representations of the world as it allegedly is". Configuration theory offers such a particular way of abstracting from reality by building ideal types and thus offering a way of conceptualizing the problem of governance (for a broader discussion see Dess et al. 1993; Meyer et al. 1993; Miller 1996; Miller and Mintzberg 1983; Short et al. 2008; Wolf 2000). While our suggested PSF governance configurations are products of ideation (Bunge 1996), they are informed by previous empirical studies of various professions. The first limitation is the empirical basis of our study consisting mainly of findings from the Anglo-American law and accounting professions. Whenever possible, we added insights from other professions or professional industries, such as architecture, consulting, advertising or investment banking. By incorporating theoretical studies and looking at the underlying factors that favor or undermine certain governance models, we attempted to reduce the problem of overgeneralization from a limited empirical basis. Nevertheless, future empirical research should focus on PSFs outside the well-researched law and accounting professions. It is likely that during these studies additional contingency factors will emerge.

A second limitation is the depth of available empirical studies, which also varies regarding the contingency factors discussed in this article. Firm size and service diversification have been studied extensively regarding PSFs and other organizations. On the contrary, how values and beliefs of professionals affect firm governance constitute a rather new research area. In addition to the more commonly proposed distinction between professional and commercial values in the PSF literature, we suggest to extend studies to explore empirically the nature and impact of entrepreneurial values.

From a managerial perspective, our configurations serve an important heuristic function in providing practitioners with design-repertoires. These general designrepertoires (a configuration is such a design repertoire) can be translated and customized to the context-specific conditions of a unique firm at hand (van Aken 2004). As the world of PSFs is changing and as PSFs are moving through different 
stages of development, our study may serve managers to evaluate how their firm's governance model should be adapted in order to respond to new emerging conditions.

Acknowledgments We would like to thank Michael Smets, Dirk Klimkeit, Tim Morris, Andreas Günther, the editor Peter Walgenbach, and three anonymous reviewers for their constructive feedback on an earlier version of this manuscript.

Open Access This article is distributed under the terms of the Creative Commons Attribution License which permits any use, distribution, and reproduction in any medium, provided the original author(s) and the source are credited.

\section{References}

Abbott, Andrew. 1988. The system of professions: an essay on the division of expert labor. Chicago: University of Chicago Press.

Aharoni, Yair. 1993. Ownership, networks and coalitions. In Coalitions and competition: the globalization of professional business services, ed. Yair Aharoni, 121-142. London: Routledge.

Aharoni, Yair. 1999. Internationalization of professional services: implication for accounting firms. In Restructuring the professional organization: Accounting, health care, and law, eds. David M. Brock, Michael J. Powell and C. R. Hinings, 21-40. London: Routledge.

Albers, Sascha. 2005. The design of alliance governance systems. Köln: Kölner Wissenschaftsverlag.

Alchian, Armen A., and Harold Demsetz. 1972. Production, information costs, and economic organization. American Economic Review 62(5): 777-795.

Alt, Jens M. 2006. Organisationswandel und Unabhängigkeit in Professional Service Firms Eine konfigurationstheoretische Analyse der Organisationsstrukturen und Anreizwirkungen unter Berücksichtigung des Fallbeispiels Arthur Andersen. Mering: Hampp.

Alvesson, Mats. 1995. Management of knowledge-intensive companies. Berlin: De Gruyter.

Amburgey, Terry L., and M. Tina Dacin. 1994. As the left foot follows the right? The dynamics of strategic and structural change. Academy of Management Journal 37(6): 1427-1452.

Anand, N., Heidi K. Gardner, and Tim Morris. 2007. Knowledge-based innovation: emergence and embedding of new practice areas in management consulting firms. Academy of Management Journal 50(2): 406-428.

Angel, Tony. 2007. Your challenge. Sustaining partnership in the twenty-first century: the global law firm experience. In Managing the Modern Law Firm, ed. Laura Empson, 196-217. Oxford: Oxford University Press.

Armbrüster, Thomas. 2006. The economics and sociology of management consulting. Cambridge: Cambridge University Press.

Augar, Philip. 2000. The death of gentlemanly capitalism: the rise and fall of London's investment banks. London: Penguin Books.

Bank, Stephan. 2006. Die britische Limited Liability Partnership. Eine attraktive Organisationsform für Freiberufler?. Duncker \& Humblot: Berlin.

Benham, Lee, and Philipp Keefer. 1991. Voting in firms: the role of agenda control, size and voter homogeneity. Economic Inquiry 29(4): 706-719.

Begum, Husnara. 2007. Partners reject lovells' plan to bypass lockstep. The Lawyer.

Berris, Julia, and Matt Byrne. 2007. Wachtell Lipton Set for Shock London Launch. The Lawyer.

Blau, Judith R. 1984. Architects and firms: a sociological perspective on architectural practice. Cambridge: MIT Press.

Bower, Joseph L. 2003. WPP-Integrating Icons to Leverage Knowledge. Harvard Business School Cases: 9-396-249.

Brint, Steven. 1994. In an age of experts. The changing role of professionals in politics and public life. Princeton: Princeton University Press.

Brock, David M. 2006. The changing professional organization: a review of competing archetypes. International Journal of Management Reviews 8(3): 157-174. 
Brock, David M., Michael J. Powell and C. R. Hinings. 1999a. The restructured professional organization. Corporates, cobwebs and cowboys. In Restructuring the professional organization: Accounting, health care, and law, eds. David M. Brock, Michael J. Powell and C. R. Hinings, 215-229. London: Routledge.

Brock, David M., Michael J. Powell and C. R. Hinings. 1999b. Restructuring the professional organization: Accounting, health care, and law. London: Routledge.

Brock, David M., Michael J. Powell and C. R. Hinings. 2007. Archetypal change and the professional srvice firm. In Research in organizational change and development, eds. William A. Pasmore and Richard W. Woodman, 221-251. Emerald.

Bromberg, Alan R., and Larry E. Ribstein. 2007. Bromberg and Ribstein on limited liability partnerships, the revised Uniform Partnership Act, and the Uniform Limited Partnership Act (2001). New York: Aspen Publishers.

Brown, John L., David J. Cooper, Royston Greenwood, and C.R. Hinings. 1996. Strategic alliances within a Big-Six accounting firm. International Studies of Management \& Organization 26(2): 59-79.

Bunge, Mario A. 1996. Finding philosophy in social science. New Haven: Yale University Press.

Capgemini. 2008. Annual Report 2007, Capgemini Group, accessed online at http://www.capgemini.com/ annual-report/2007/. Paris.

Capgemini. 2009a. Annual Report 2008, Capgemini Group, accessed online at http://www.annualreport. capgemini.com/en/telechargement. Paris

Capgemini. 2009b. Financial Report 2008, Capgemini Group, accessed online at http://www. annualreport.capgemini.com/en/telechargement. Paris.

Carter-Pegg, Nick and Ben Potter. 2006. Limited appeal. The Lawyer.

Child, John. 1972. Organizational structure, environment and performance: the role of strategic choice. Sociology 6(1): 1-22.

Clark, Burton R. 1998. Creating entrepreneurial universities: organizational pathways of transformation. Oxford: Pergamon Press.

Cooper, David J., C.R. Hinings, Royston Greenwood, and John L. Brown. 1996. Sedimentation and transformation in organizational change: the case of Canadian law firms. Organization Studies 17(4): 623.

DeLong, Thomas J. 2003. Strategic services at Andersen Consulting. In Professional services: text and cases, ed. Thomas J. DeLong, and Ashish Nanda, 281-295. New York: McGraw-Hill/Irwin.

Demsetz, Harold. 1983. The structure of ownership and the theory of the firm. Journal of Law and Economics 26(2): 375-390.

Dess, Gregory G., Stephanie Newport, and Abdul M.A. Rasheed. 1993. Configuration research in strategic management: key issues and suggestions. Journal of Management 19(4): 775-795.

Dow, Gregory K., and Louis Putterman. 2000. Why capital suppliers (usually) hire workers: what we know and what we need to know. Journal of Economic Behavior \& Organization 43(3): 319-336.

Empson, Laura. 2006. Professionals in partnership. In Production values: futures of professionalism, ed. John Craig, 144-152. London: Demos.

Empson, Laura. 2007. Your partnership. Surviving and thriving in a changing world: the special nature of partnership. In Managing the modern law firm, ed. Laura Empson, 10-36. Oxford.

Empson, Laura. 2012. Beyond dichotomies: a multi-stage model of governance in professional service firms. In Handbook of research on entrepreneurship in professional services, ed. Markus Reihlen, and Andreas Werr, 274-294. Cheltenham: Edgar Elgar.

Empson, Laura, and Chris Chapman. 2006. Partnership versus corporation: implications of alternative forms of governance in professional service firms. Research in the Sociology of Organizations 24: 139-170.

Fama, Eugene F., and Michael C. Jensen. 1983a. Agency problems and residual claims. Journal of Law and Economics 26(2): 327-349.

Fama, Eugene F., and Michael C. Jensen. 1983b. Separation of ownership and control. Journal of Law and Economics 26(2): 301-325.

Farrell, Joseph, and Suzanne Scotchmer. 1988. Partnerships. Quarterly Journal of Economics 103(2): 279-297.

Freedman, Judith and Vanessa Finch. 1997. Limited liability partnerships: Have accountants sewn up the 'deep pockets' debate? The Journal of Business Law 387-423.

Gallese, Liz R. 1989. Counselor to the King. New York Times.

Galanter, Marc, and Thomas Palay. 1991. Tournament of lawyers: the transformation of the big law firm. Chicago: University of Chicago Press. 
Gilson, Ronald J., and Robert H. Mnookin. 1985. Sharing among the human capitalists: an economic inquiry into the corporate law firm and how prtners split profits. Stanford Law Review 37(2): 313-392.

Gilson, Ronald J., and Robert H. Mnookin. 1989. Coming of age in a corporate law firm: the economics of associate career patterns. Stanford Law Review 41(3): 567-595.

Grabher, Gernot. 2001. Ecologies of creativity: the village, the group, and the heterarchic organisation of the British advertising industry. Environment and Planning A 33(2): 351-374.

Graubner, Michael. 2006. Task, firm size, and organizational structure in management consulting: an empirical analysis from a contingency perspective. Wiesbaden: Deutscher Universitätsverlag.

Greenwood, Royston. 2007. Your ethics. Redefining professionalism. The impact of management change. In Managing the modern law firm, ed. Laura Empson, 186-195. Oxford.

Greenwood, Royston, David J. Cooper, C.R. Hinings, and John L. Brown. 1993. Biggest is best? Strategic assumptions and actions in the Canadian audit industry. Canadian Journal of Administrative Sciences 10(4): 308-321.

Greenwood, Royston, and Laura Empson. 2003. The professional partnership: relic or exemplary form of governance? Organization Studies 24(6): 909-933.

Greenwood, Royston, and C.R. Hinings. 1993. Understanding strategic change: the contribution of archetypes. Academy of Management Journal 36(5): 1052-1081.

Greenwood, Royston, C.R. Hinings, and John Brown. 1990. " $\mathrm{P}^{2}$-form" strategic management: corporate practices in professional partnerships. Academy of Management Journal 33(4): 725-755.

Greenwood, Royston, Tim Morris, Samantha Fairclough, and Mehdi Boussebaa. 2010. The organizational design of transnational professional service firms. Organizational Dynamics 39(2): 173-183.

Greenwood, Royston, and Roy Suddaby. 2006. Institutional entrepreneurship in mature fields: the Big Five accounting firms. Academy of Management Journal 49(1): 27-48.

Greenwood, Royston, Roy Suddaby, and C.R. Hinings. 2002. Theorizing change: the role of professional associations in the transformation of institutionalized fields. Academy of Management Journal 45(1): $58-80$.

Griffiths, Catrin. 2005. Clifford chance partnership votes in three-tier lockstep. The Lawyer.

Günther, Andreas. 2012. Entrepreneurial strategies of professional service firms: an analysis of commercial law firm spin-offs in Germany. Köln: Kölner Wissenschaftsverlag.

Hall, Richard H. 2002. Organizations. Structures, processes, and outcomes. Upper Saddle River: Prentice-Hall.

Hansen, Morten T., Nitin Nohria, and Thomas J. Tierney. 1999. What's your strategy for managing knowledge? Harvard Business Review 77(2): 106-118.

Hansmann, Henry. 1996. The ownership of enterprise. Cambridge: Belknap Harvard.

Harlacher, Dirk. 2010. The Governance of professional service firms (PhD-thesis). Köln: Kölner Wissenschaftsverlag.

Harris, Joanne. 2005. More than third of firms eschew LLP conversion. The Lawyer.

Hinings, C.R., John L. Brown, and Royston Greenwood. 1991. Change in an autonomous professional organization. Journal of Management Studies 28(4): 375-393.

Hinings, C. R., Royston Greenwood and David Cooper. 1999. The dynamics of change in large accounting firms. In Restructuring the professional organization: Accounting, health care and law, eds. David M. Brock, Michael J. Powell and C. R. Hinings, 131-153. London: Routledge.

Hinings, C.R., and Gloria L. Lee. 1971. Dimensions of organization structure and their context: a replication. Sociology 5(1): 83-93.

Illman, James. 2007. What Marty Says... Legal Week 24-25.

Jones, Leigh. 2006. Law firms look at closing pay systems. The National Law Journal.

Kaiser, Stephan, and Max Josef Ringlstetter. 2011. Strategic management of professional service firms: theory and practice. Heidelberg: Springer.

Kieser, Alfred, and Peter Walgenbach. 2007. Organisation. Stuttgart: Schäffer-Poeschel.

Kolz, Amy. 2007. To Miami's Greenberg Traurig, Culture is No Vice. Legal Times.

Koza, Mitchell P., and Arie Y. Lewin. 1999. The coevolution of network alliances: a longitudinal analysis of an international professional service network. Organization Science 10(5): 638-653.

Klimkeit, Dirk and Markus Reihlen. 2012. Local responses to global integration in a transnational professional service firm. Paper presented at the Annual Meeting of the Academy of Management.

Kummel, William. 1996. A market approach to law firm economics. A new model for pricing, billing, compensation and ownership in corporate legal services. Columbia Business Law Review 11(2): 379-422. 
Lawrence, Paul R., and Jay W. Lorsch. 1967. Organization and environment. Managing differentiation and integration. Cambridge: Harvard University Press.

Leibowitz, Arleen, and Robert Tollison. 1980. Free riding, shirking, and team production in legal partnerships. Economic Inquiry 18(3): 380-394.

Lenz, Hansrudi and M. L. James. 2006. International audit firms as strategic networks: the evolution of global professional service firms. In Economics and management of networks. Franchising, strategic alliances, and cooperatives, ed. Gérard P. H. Cliquet. Heidelberg: Physica-Verlag.

Levin, Jonathan, and Steven Tadelis. 2005. Profit sharing and the role of professional partnerships. Quarterly Journal of Economics 120(1): 131-172.

Lipton, Martin. 1990. The Firm at Twenty-five. New York: Unpublished Work.

Lorsch, Jay W. and Samantha K. Graff. 1995. "Marketing” at Wachtell, Lipton, Rosen \& Katz, pp. 1-8. Harvard Business School Cases: 9-496-037.

Lorsch, Jay W., and Thomas J. Tierney. 2002. Aligning the stars: How to succeed when professionals drive results. Boston: Harvard Business School Press.

Løwendahl, Bente. 2005. Strategic management of professional service firms. Copenhagen: CBS Press.

Maister, David H. 1993. Managing the professional service firm. New York: Free Press.

Malhotra, Namrata, Timothy Morris, and C.R. Hinings. 2006. Variation in organizational form among professional service organizations. Research in the Sociology of Organizations 24: 171-202.

McCahery, Joseph A. 2004. Introduction: governance in partnership and close corporation law in Europe and the United States. In The governance of close corporations and partnerships. US and European perspectives, ed. Joseph A. McCahery, Theo Raaijmakers, and Erik P. Vermeulen, 1-19. Oxford: Oxford University Press.

McCahery, Joseph A., and Erik P. Vermeulen. 2004. The evolution of closely held business forms in Europe. In The governance of close corporations and partnerships. US and European perspectives, ed. Joseph A. McCahery, Theo Raaijmakers, and Erik P. Vermeulen, 191-240. Oxford: Oxford University Press.

McKenna, Christopher D. 2006. The world's newest profession. New York: Cambridge University Press.

Mehran, Hamid, and René Stulz. 2007. The economics of conflicts of interest in financial institutions. Journal of Financial Economics 85(2): 267-296.

Meyer, Alan D., Anne S. Tsui, and C.R. Hinings. 1993. Configurational approaches to organizational analysis. Academy of Management Journal 36(6): 1175-1195.

Miles, Raymond E., and Charles C. Snow. 1978. Organizational strategy, structure and process. New York: McGraw-Hill.

Miller, Danny. 1981. Toward a new contingency approach: the search for organizational gestalts. Journal of Management Studies 18(1): 1-26.

Miller, Danny. 1986. Configurations of strategy and structure: towards a synthesis. Strategic Management Journal 7(3): 233-249.

Miller, Danny. 1987. The genesis of configuration. Academy of Management Review 12(4): 686-701.

Miller, Danny. 1996. Configurations revisited. Strategic Management Journal 17(7): 505-512.

Miller, Danny, and Peter H. Friesen. 1984. Organizations: a quantum view. Englewood Cliffs: PrenticeHall.

Miller, Danny, and Henry Mintzberg. 1983. The case for configuration. In Beyond Method, ed. G. Morgan, 57-73. Beverly Hills: Sage.

Mintzberg, Henry. 1979. The structuring of organizations. Englewood Cliffs: Prentice-Hall.

Mintzberg, Henry. 1983. Power in and around organizations. Englewood Cliffs: Prentice-Hall.

Mintzberg, Henry. 1990. Strategy formation: schools of thought. In Perspectives on strategic management, ed. James W. Fredrickson, 105-236. New York: Harper Business.

Montagna, Paul D. 1968. Professionalization and bureaucratization in large professional organizations. American Journal of Sociology 74(2): 138-145.

Morris, Timothy, and Laura Empson. 1998. Organization and expertise: an exploration of knowledge bases and the management of accounting and consulting firms. Accounting, Organizations and Society 23(5/6): 609-624.

Morris, Timothy, and Ashly Pinnington. 1998. Promotion to partner in professional service firms. Human Relations 51(1): 3-24.

Morris, Timothy and Ashly Pinnington. 1999. Continuity and change in professional organizations: evidence from British law firms. In Restructuring the professional organization: Accounting, health care and law, eds. David M. Brock, Michael J. Powell and C. R. Hinings, 200-214. London: Routledge. 
Morrison, Alan D., and William J. Wilhelm. 2004. Partnership firms, reputation, and human capital. American Economic Review 94(5): 1682-1692.

Morrison, Alan D., and William J. Wilhelm. 2007. Investment banking: past, present, and future. Journal of Applied Corporate Finance 19(1): 42-54.

Morrison, Alan D., and William J. Wilhelm. 2008. The demise of investment banking partnerships: theory and evidence. Journal of Finance 63(1): 311-350.

Morse, Geoffrey. 2004. Limited liability partnerships and partnership law reform in the United Kingdom. In The governance of close corporations and partnerships. US and European perspectives, ed. Joseph A. McCahery, Theo Raaijmakers, and Erik P. Vermeulen, 317-346. Oxford: Oxford University Press.

Nanda, Ashish. 2003. Family feud (A): Andersen versus Andersen. In Professional Services: Text \& Cases, ed. Thomas J. DeLong, and Ashish Nanda, 203-223. New York: McGraw-Hill/Irwin.

Nelson, Robert L. 1988. Partners with power: the social transformation of the large law firm. Berkeley: University of California Press.

O'Leary, Christopher. 2007. Cracks in the Chinese Wall. Investment Dealers' Digest 73(9): 18-22.

Ouchi, William G. 1979. A conceptual framework for the design of organizational control mechanisms. Management Science 25(9): 833-848.

Ouchi, William G. 1980. Markets, bureaucracies, and clans. Administrative Science Quarterly 25(1): 129-141.

Pinnington, Ashly, and Timothy Morris. 1996. Power and control in professional partnerships. Long Range Planning 29(6): 842-849.

Pinnington, Ashly, and Timothy Morris. 2002. Transforming the architect: ownership form and archetype change. Organization Studies 23(2): 189-210.

Pinnington, Ashly, and Timothy Morris. 2003. Archetype change in professional organizations: survey evidence from large law firms. British Journal of Management 14(1): 85-99.

Power, Helen, and Husnara Begum. 2004. Freshfields Bangkok Axed in Asia Review. The Lawyer.

Pugh, Derek S., David J. Hickson, and C.R. Hinings. 1969. An empirical taxonomy of structures of work organizations. Administrative Science Quarterly 14(1): 115-126.

Rebitzer, James B., and Lowell J. Taylor. 2007. When knowledge is an asset: explaining the organizational structure of large law firms. Journal of Labor Economics 25(2): 201-229.

Reihlen, Markus, Sascha Albers, and Tuulia Kewitz. 2009. Internationalization as strategic change: the case of Deutsche Treuhand-Gesellschaft. Management revue 20(2): 209-233.

Reihlen, Markus, and Ferdinand Wenzlaff. 2014. Institutional change of the German higher education system: From professional dominance to managed education. In Handbook on the entrepreneurial university, ed. Dana Redford, and Alain Fayolle, 112-135. Cheltenham: Edward Elgar.

Rorty, R. 1991. Objectivity, relativism, and truth. Cambridge: Cambridge University Press.

Rose, T. and C. R. Hinings. 1999. Global clients' demands driving change in global business advisory firms. In Restructuring the professional organization: Accounting, health care and law, eds. David M. Brock, Michael J. Powell and C. R. Hinings, 41-67. London: Routledge.

Rumelt, Richard P. 1974. Strategy, structure, and economic performance. Cambridge: Harvard University Press.

Sherer, Peter D. 2007. Your competitors. Mapping the competitive space of large US law firms. In Managing the modern law firm, ed. Laura Empson, 162-185. Oxford: Oxford University Press.

Sherer, Peter D., and Kyungmook Lee. 2002. Institutional change in large law firms: a resource dependency and institutional perspective. Academy of Management Journal 45(1): 102-119.

Short, Jeremy C., G. Tyge Payne, and David J. Ketchen Jr. 2008. Research on organizational configurations: past accomplishments and future challenges. Journal of Management 34(6): 1053-1079.

Smets, Michael, Timothy Morris, and Namrata Malhotra. 2012. New career models and capacity for innovation in professional services. In Handbook of research on entrepreneurship in professional services, ed. Markus Reihlen, and Andreas Werr, 127-147. Cheltam: Edward Elgar.

Smigel, Erwin O. 1969. The Wall Street lawyer: professional organization man?. Bloomington: Indiana University Press.

Smirchich, Linda. 1983. Concepts of culture and organizational analysis. Administrative Science Quarterly 28(3): 339-358.

Starbuck, William H. 1993. Keeping a butterfly and an elephant in a house of cards: the elements of exceptional success. Journal of Management Studies 30(6): 885-921. 
Suddaby, Roy, Yves Gendronb, and Helen Lamc. 2009. The organizational context of professionalism in accounting. Accounting, Organizations and Society 34(3-4): 409-427.

Swaine, Robert T. 1948. The Cravath firm and its predecessors 1819-1948, Vol. 2. New York: Ad Press.

Tolbert, Pamela S., and Robert N. Stern. 1991. Organizations of professionals: Governance structures in large law firms. In Organizations and professions, ed. Pamela S. Tolbert, and Stephen R. Barley, 97-113. Greenwich: JAI Press.

van Aken, Joan E. 2004. Management research based on the paradigm of the design sciences: the quest for field-tested and grounded technological rules. Journal of Management Studies 41(2): 219-246.

von Nordenflycht, Andrew. 2007. Is public ownership bad for professional service firms? Ad agency ownership, performance, and creativity. Academy of Management Journal 50(2): 429-445.

von Nordenflycht, Andrew. 2009. Firm size and industry structure under human capital intensity: insights from the evolution of the global advertising industry. Organization Science 22(1): 141-157.

von Nordenflycht, Andrew. 2010. What is a professional service firm? Towards a taxonomy of knowledge intensive firms. Academy of Management Review 35(1): 155-174.

Weber, Max. 1978. Economy and society: an outline of interpretive sociology. Berkeley: University of California Press.

Wilhelm, William J., and Joseph D. Downing. 2001. Information markets: what businesses can learn from financial innovation. Cambridge: Harvard Business School Press.

Williams, Kylie. 2007. Profession-wide move to merit-based remuneration tolls death knell for PQE. Lawyer 21(34): 4.

Williamson, Oliver E. 1975. Markets and hierarchies: analysis and antitrust implications. New York: The Free Press.

Williamson, Peter J. and Michael Y. Yoshino. 1994. Bain \& Company: International Expansion, pp. 1-32. Harvard Business School Cases: 9-395-102.

Wissema, Johan Gooitzen. 2009. Towards the third generation university: Managing the university in transition. Cheltenham: Edward Elgar. In Der Gestaltansatz in der Management- und Organisationslehre ed. Wolf, Joachim (2000). Wiesbaden:Gabler.

Wolf, Joachim. 2000. Der Gestaltansatz in der Management- und Organisationslehre. Wiesbaden: Gabler. 